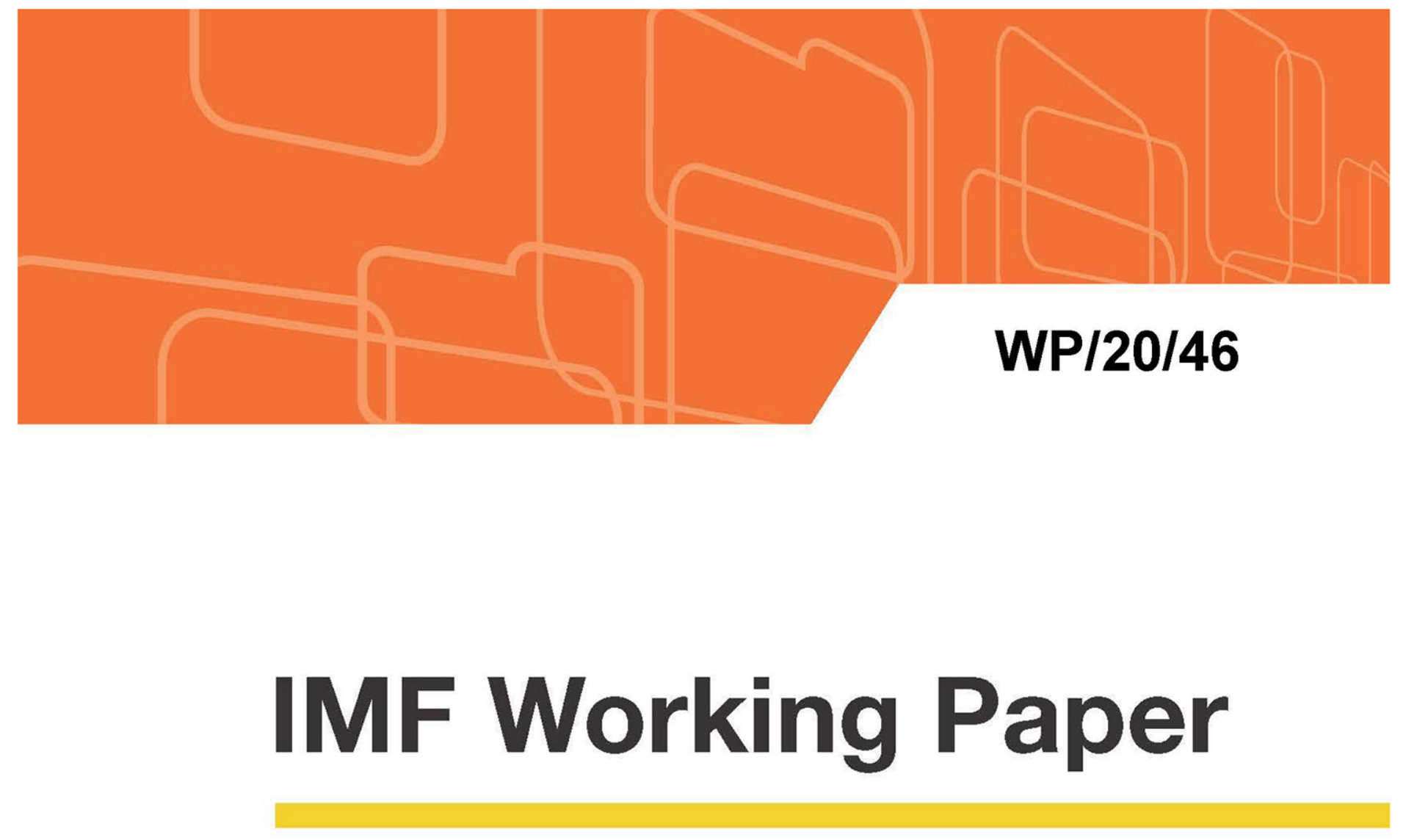

\title{
International Capital Flows at the Security Level - Evidence from the ECB's Asset Purchase Programme
}

by Katharina Bergant, Michael Fidora, and Martin Schmitz

IMF Working Papers describe research in progress by the author(s) and are published to elicit comments and to encourage debate. The views expressed in IMF Working Papers are those of the author(s) and do not necessarily represent the views of the IMF, its Executive Board, or IMF management.

$$
\text { I N T E R N A T I O N A L M O N E T A R Y FU N D }
$$




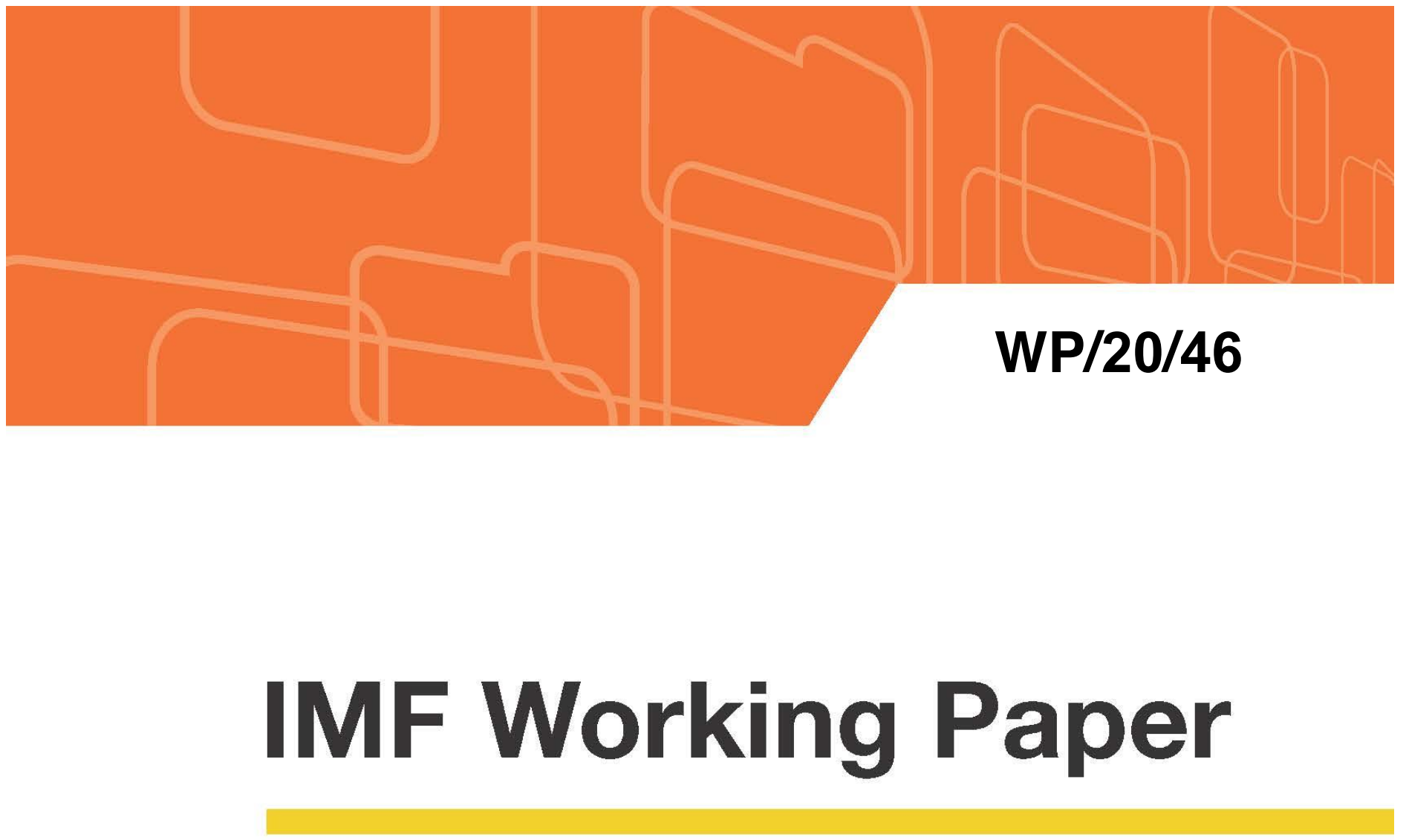

\section{International Capital Flows at the Security Level - Evidence from the ECB's Asset Purchase Programme}

by Katharina Bergant, Michael Fidora, and Martin Schmitz

IMF Working Papers describe research in progress by the author(s) and are published to elicit comments and to encourage debate. The views expressed in IMF Working Papers are those of the author(s) and do not necessarily represent the views of the IMF, its Executive Board, or IMF management.

$$
\text { I N T E R N A T I O N A L M O N E T A R Y F U N D }
$$




\title{
IMF Working Paper
}

\author{
Research Department
}

\section{International Capital Flows at the Security Level - Evidence from the ECB's Asset Purchase Programme ${ }^{1}$}

\section{Prepared by Katharina Bergant, Michael Fidora, and Martin Schmitz}

Authorized for distribution by Malhar Nabar

February 2020

\section{IMF Working Papers describe research in progress by the author(s) and are published to elicit comments and to encourage debate. The views expressed in IMF Working Papers are those of the author(s) and do not necessarily represent the views of the IMF, its Executive Board, or IMF management.}

\begin{abstract}
We analyse euro area investors' portfolio rebalancing during the ECB's Asset Purchase Programme at the security level. Our empirical analysis shows that euro area investors (in particular investment funds and households) actively rebalanced away from securities targeted under the Public Sector Purchase Programme and other euro-denominated debt securities, towards foreign debt instruments, including 'closest substitutes', i.e. certain sovereign debt securities issued by non-euro area advanced countries. This rebalancing was particularly strong during the first six quarters of the programme. Our analysis also reveals marked differences across sectors as well as country groups within the euro area, suggesting that quantitative easing has induced heterogeneous portfolio shifts.
\end{abstract}

JEL Classification Numbers: F21, F42, E52, G15

Keywords: International investment patterns, capital flows, sovereign debt, investor heterogeneity, quantitative easing

Author's E-Mail Address: KBergant@imf.org

\footnotetext{
${ }^{1}$ We are grateful for insightful discussions and comments from Katrin Assenmacher, Michael Bauer, Ettore Dorrucci, Serdar Kabaca, Sebnem Kalemli-Ozcan, Philip Lane, Wolfgang Lemke, Arnaud Mehl, Elias Papaioannou, Peter Praet, Antonio Rodriguez Caloca, Livio Stracca, and Fabrizio Venditti. The paper has won the Best Paper Award by the CEPS European Capital Markets Institute and was presented at their 8th Annual Conference.
} 
TABle Of Contents

ABSTRACT

1. INTRODUCTION

2. EMPIRICAL FRAMEWORK

2.1. Data

2.2. Econometric Approach

2.3. Empirical Implementation

3. DESCRIPTIVE EVIDENCE ON EURO AREA REBALANCING DURING THE PSPP PERIOD

3.1. Debt Securities

3.2. Beyond Debt Securities

3.3. Geography, Currency, and Maturity

\section{ECONOMETRIC EVIDENCE ON EURO AREA REBALANCING DURING THE} PSPP

4.1. Overall Results

4.2. Sector Heterogeneity

4.3. Geography

4.4. Country Heterogeneity

4.5. Time Dynamics

4.6. Active vs. Passive Rebalancing

\section{FIGURES}

Figure 1: Breakdown of euro area net portfolio investment flow

Figure 2: Breakdown of euro area portfolio investment outflows

Figure 3: Average Yield to Maturity

Figure 4: Euro area net debt transactions

Figure 5: Euro area net debt transactions by sector

Figure 6: Euro area net debt transactions by country $\underline{33}$

Figure 7: Euro area net transactions: intra-(LHS) and extra-euro area (RHS)

Figure 8: Euro area net transactions by sector: intra-(LHS) and extra-euro area (RHS) 34 Figure 9: Euro area net transactions by country: intra-(LHS) and extra-euro area (RHS) _ 35 Figure 10: Euro area net transactions of investment fund shares split by their main mandate $\underline{35}$ Figure 11: Euro area net transactions by geography: debt (LHS) and equity (RHS) Figure 12: Euro area net transactions by currency: debt (LHS) and equity (RHS) Figure 13: Euro area net transactions by currency: debt (LHS) and equity (RHS) 
Figure 14: Euro area net debt transactions by maturity

Figure 15: Euro area net debt transactions by maturity

Figure 16: Euro area net transactions, changes in holdings and valuation effects in PSPP __ $\underline{39}$

\section{TABLES}

Table 1: Baseline estimation: debt securities $\underline{40}$

Table 2: Sectoral estimation: debt securities

Table 3: Geography estimations $\underline{42}$

Table 4: Country-group estimation $\underline{43}$

Table 5: Extension of the baseline estimation: Time Dimension $\underline{44}$

Table 6: Time Dimension and PSPP eligibility: overall and by sector $\underline{45}$

Table 7: Extension: Active vs. Passive Rebalancing and PSPP eligibility 46 


\section{Introduction}

Large scale asset purchase programmes (LSAPs) by central banks have become a popular tool of unconventional monetary policy since the global financial crisis to stimulate economic growth and fulfil inflation objectives in a zero lower bound environment. A major transmission channel of these policies to the real economy is portfolio rebalancing towards higher yielding domestic as well as foreign assets.

The European Central Bank's (ECB) unconventional monetary policy measures, covering the large scale Asset Purchase Programme (APP), a negative deposit rate, and targeted longer-term refinancing operations (TLTROs), reduced euro area long-term risk-free rates by around 80 basis points in the period June 2014 to December 2016 (ECB, 2017b). The resulting yield differentials between euro area and foreign government bonds played an important role for euro area capital flows (ECB, 2017a). Evidence from the euro area balance of payments shows that the introduction of the main component of the APP - namely the Public Sector Purchase Programme (PSPP) - was followed by significant net capital outflows (Figure 1). ${ }^{1}$ At their peak in mid-2016, net outflows of portfolio investment reached an all-time high of nearly 5\% of euro area GDP (Coeure, 2017). While non-residents account for a sizable share of bond sales to the Eurosystem, euro area investors have been a major driving force behind the observed net outflows (Figure 2). Since the start of the PSPP in March 2015, net purchases of foreign securities by domestic investors took place almost entirely in the form of long-term bonds suggesting that domestic investors partly rebalanced their portfolios towards the closest substitute to PSPP eligible assets outside the euro area. In addition, the APP triggered substantial intra-euro area liquidity flows related to portfolio rebalancing which were partly reflected in rising TARGET balances (Eisenschmidt et al., 2017).

This macro-based evidence shows that LSAPs can trigger substantial cross-border capital flows by way of the portfolio rebalancing channel. In an integrated international financial system, monetary policy impacts both domestic investment patterns and international capital flows. The growing complexity and interconnectedness of the international financial system as well as sector heterogeneity provide a strong case for incorporating micro data for policy analysis (Lane, 2015). Limitations of macro data pertain for instance to the limited extent of sectoral information on holders and issuers of assets, both in a domestic and cross-border context. Consistent country-level data on capital flows are usually only available unilaterally, while bilateral data merely cover investment positions, are available at low frequencies, and do not include the holdings of domestic securities (e.g. the IMF's Coordinated Portfolio Investment Survey, CPIS). Finally, only security-by-security data allow identifying important asset specific characteristics such as the issuing entity, the yield and market prices, as well as the currency denomination, rating, or the maturity.

\footnotetext{
${ }^{1}$ The PSPP accounted for approximately $80 \%$ of the entire APP in the period until end 2016.
} 
The objective of this paper is to analyse the capital outflows observed during the APP programme at a very granular level. In doing so, we seek to answer the question whether euro area investors did rebalance away from the very same securities that were targeted by the ECB during the APP. Moreover: what securities did euro area investors buy outside the euro area (i.e. securities issued by which countries and sectors), thereby creating global spillovers from the ECB's policies? What were the determinants of these capital flows? Were there heterogeneous investment patterns across euro area sectors and countries?

To answer these questions, we use security-by-security data from the European System of Central Banks' (ESCB) Securities Holding Statistics by sector (SHSS) which offers a comprehensive, fully integrated, granular dataset of the security holdings of euro area residents. Our dataset allows for providing a detailed account of euro area portfolio rebalancing over the first eight quarters of the PSPP period (2015Q1 to 2016Q4) - both at the country and sector level, incorporating domestic, euro area and global capital flows of euro area residents. ${ }^{2}$

Our paper is the first - to the best of our knowledge - to analyse actual capital flows (i.e. net purchases or net sales) at the security level in a bilateral cross-country-sector setting. ${ }^{3}$ With our empirical specification of sectoral, bilateral capital flows at the security level, we are able to test several hypotheses with regard to the impact of the APP on portfolio rebalancing. Moreover, as our dataset includes holdings as well as transactions of individual securities, we are able to decompose the overall portfolio rebalancing of euro area investors into 'active' (i.e. capital flows) and 'passive' components (i.e. valuation changes due to fluctuations in security prices and exchange rates), following the intuition of Tille and van Wincoop (2010).

The SHSS data encompass security holdings and transactions of all economic sectors in euro area countries (with the exception of the monetary authorities), rather than singling out a specific country or sector. Exploiting this allows for examining heterogeneity among investors along various dimensions. We argue that it is crucial to consider sectoral heterogeneity, especially when analysing the PSPP, due to differing initial positions at the start of the programme (most notably in terms of exposure to public sector bonds, ECB (2017c)), different degrees of investor sophistication, informational frictions, or different asset and liability management strategies as well as regulatory constraints which may imply heterogeneous responses.

Our paper contributes to the literature on the cross-border impact of LSAPs, which was initially triggered by the first rounds of the Federal Reserves' quantitative easing (QE). Neely (2010) shows that the Fed's QE significantly reduced not only domestic, but also foreign long-term bond

\footnotetext{
${ }^{2}$ As such we are able to integrate the analysis of domestic and international sectoral portfolios, similar to Heipertz et al. (2016) who use data on French sectoral portfolios to estimate how different sectors are affected by balance sheet contagion.

${ }^{3}$ While Boermans and Vermeulen (2016) also use information on positions from the SHSS data, their analysis focuses on the cross-sectional determinants of security holdings before the APP, rather than on transactions.
} 
yields, while Moore et al. (2013) find that QE also resulted in a significant increase in the foreign ownership of emerging market debt securities. The channels through which QE affects international portfolio rebalancing emerge from the transmission channels of unconventional monetary policy in the domestic economy. Beyond pure 'scarcity' effects, LSAPs can work through the signalling effect, the extraction of duration risk, as well as the risk-taking, confidence and inflation channels (Krishnamurthy and Vissing-Jorgensen, 2011).

In general, international portfolio rebalancing will occur in response to an absorption of the supply of safe long-term bonds by the central bank under QE. If unconventional monetary policy is successful in raising the price and lowering the yields of such assets, investors will seek higher yielding assets abroad. These effects may be reinforced via the duration risk channel as the reduced supply will induce investors to accept a smaller term premium for long-term bonds which further lowers their yields and increases their incentives to invest in higher yielding foreign assets (Chari et al., 2017). In particular, rebalancing may happen towards bonds with similar characteristics via "preferred-habitat investors" (Vayanos and Vila, 2009), but also towards riskier assets under the risk-taking channel.

Moreover, under the signalling channel, investors may perceive a credible commitment by the central bank to keep also short-term rates - despite not directly targeted by QE - low for a considerable period of time. This gives rise to persistent interest rate differentials which in turn could incentivise cross-border carry trades (Neely, 2010). Related to the former, under the inflation channel, investors may expect higher inflation rates in the future and - under the purchasing power parity hypothesis - a depreciation of the currency which would further trigger appetite for foreign assets. Furthermore, unconventional monetary policy may affect international capital flows via the confidence channel. If financial markets extract private information from QE on the central bank's economic outlook, this may affect investor sentiment and risk aversion.

There is a broad consensus that the ECB's APP persistently reduced euro area long-term bond yields, both of targeted and other debt securities, while also boosting equity prices via the signalling channel (Altavilla et al. (2015) and Andrade et al. (2016)). Event-studies focusing on the ECB's APP announcement show that the effect on investor sentiment had significant spillovers to the rest of the European Union (EU) and global equity markets (Falagiarda et al. (2015); Georgiadis and Graeb (2016)). Examining the impact of monetary policy surprises associated with the ECB's APP, Bubeck et al. (2017) present high-frequency event-study evidence on the investment behaviour of mutual funds based in Luxembourg. They distinguish between an active channel (transactions) and a passive channel (changes in the value), of which they find only the latter to be a significant driver of portfolio rebalancing at the daily frequency.

Our paper contributes to the literature on portfolio rebalancing using microdata. This strand 
has grown over time, but usually focuses only on a particular sector or country: Calvet et al. (2009) examine the portfolio rebalancing of Swedish households and Hau et al. (2017) find that international equity funds rebalance from foreign investment after making excess returns relative to their domestic equity investment. While we follow this literature and use fixed effects for the holder and issuer country pairs to control for incomplete asset markets and transaction costs in international asset trade, we also contribute to the broader literature analysing the determinants of international capital flows by incorporating the concept of "push" and "pull" factors in our analysis. Since seminal papers have shown evidence of their significance as drivers of international capital flows (Calvo et al. (1993, 1996), Fernandez-Arias (1996), Chuhan et al. (1998), Griffin et al. (2004)), push and pull determinants have received significant attention, especially in the aftermath of the global financial crisis (Fratzscher (2012), Forbes and Warnock (2012), and more recently Cerutti et al. (2017)) and McQuade and Schmitz (2019).

In contrast to other contributions using the SHSS dataset, we are the first to use actual data on net transactions at the euro area level: Koijen et al. (2018) assess rebalancing by using information on changes in security holdings and show for the period 2015Q2 until 2016Q4 that foreign investors rebalanced most in response to the ECB's PSPP purchases, followed by euro area banks and mutual funds. Albertazzi et al. (2018) find that portfolio rebalancing played a relevant role in the transmission of the ECBs APP, but with important differences across countries. Boermans and Vermeulen (2018) suggest that euro area investors preference for holding bonds with certain characteristics ("preferred habitat") remained stable during the APP. Analysing net transactions by Irish investment funds, Bua and Dunne (2019) find significant evidence of portfolio rebalancing away from euro area government bonds, but only after the PSPP was scaled up in June 2016.

The rest of the paper is organised as follows: In Section 2, we introduce our dataset and the empirical framework. We provide descriptive evidence on the portfolio rebalancing of euro area investors since the launch of the APP in Section 3. Section 4 presents our econometric results and Section 5 concludes.

\section{Empirical Framework}

\subsection{Data}

We use data on security-level portfolio holdings and transactions of all 19 euro area countries from the ESCB Securities Holding Statistics (SHSS). ${ }^{4}$ The data are collected by national central banks

\footnotetext{
${ }^{4}$ This dataset is collected according to Regulation ECB/2012/24, see http://www.ecb.europa.eu/ecb/legal/pdf/ 1_30520121101en00060024.pdf
} 
from (i) financial investors and (ii) custodians. It covers all short-term and long-term debt securities, listed shares, as well as investment fund shares that are identified with a unique International Securities Identification Number (ISIN). This split into financial instruments is in line with those included in national accounts or balance of payments statistics. The data are collected on a quarterly basis since 2013Q4 and we use releases until 2016Q4 for this analysis. The SHSS data consist of directly and indirectly reported securities. A financial institution resident in the euro area is obliged to report securities that it holds as its own investment ("direct reporting") as well as securities that it holds in custody ("indirect reporting"). In order to avoid double reporting, only assets held in custody for non-financial investors (mainly households and non-financial corporations) are included in the SHSS. ${ }^{5}$ Investors in the data are defined by their country of domicile and sector. We follow the European System of Accounts (2010) and aggregate the data to six sectors: monetary and financial institutions (MFI) excluding monetary authorities, insurance companies and pension funds (ICPF), other financial institutions (OFI) ${ }^{6}$, non-financial corporations (NFCs), general government and households. ${ }^{7}$ Using the ISIN for every security, we merge the SHSS data to individual asset characteristics obtained from the ESCB's Centralised Securities Database (CSDB) which contains information on more than six million debt and equity securities issued globally. Therefore, we can use information at the security-level, such as the instrument type, issuer country and institutional sector, currency of denomination, yields and original maturity.

\subsection{Econometric approach}

Our paper builds on the literature estimating the determinants of international investment patterns and extends it by analysing the drivers of euro area investors' international capital flows at the security-level for the APP period. We specify the model

$$
\ln \left(\text { flow }_{a, i, j, t}\right)=\beta_{d}^{0} \ln \left(A_{a, i, j, t-1}\right)+\beta_{d}^{1} * x_{a, t}^{1}+\ldots+\beta_{d}^{k} * x_{a, t}^{k}+\gamma_{h, s}+\alpha_{i}+\alpha_{j}+\epsilon_{a, i, j}
$$

where $\ln \left(\right.$ flow $\left._{a, i, j, t}\right)$ represents the log of country-sector $i$ 's net transactions (i.e. net sales or purchases) accumulated over $t$ (i.e. the PSPP period 2015Q1-2016Q4) of security $a$ issued by countrysector $j .{ }^{8}$ The dependent variable is regressed on pre-PSPP holdings of a security $\ln \left(A_{a, i, j, t-1}\right)$, defined as holdings at the end of 2014Q4, which are included in order to control for the pre-existing

\footnotetext{
${ }^{5}$ Double-counting could occur if there are several intermediate financial institutions between the final non-financial investor and the financial institution holding assets in custody.

${ }^{6}$ These include important intermediaries such as mutual funds which represent the largest subgroup of this sector.

${ }^{7}$ As for Balance of Payments statistics, one potential shortcoming of the dataset is the incomplete coverage of securities held in custody outside the euro area by the non-financial sector.

${ }^{8}$ If net transactions over 2015Q1-2016Q4 are negative (indicating net sales of a security by a sector), we follow Levy Yeyati et al. (2007) and take the logarithm of the absolute value and multiply it with -1 to allow for a log distribution also in the case of net sales.
} 
'level' of a sector's investment in a specific security. ${ }^{9}$ Due to the granularity of our dataset, we are able to control for asset specific characteristics $\left(x_{a, t}^{k}\right)$ that may influence investment behaviour directly. Our main variables of interest are (i) PSPP Eligible which is a dummy variable equal to one if the security is eligible to be bought under PSPP and (ii) PSPP Substitute which is a dummy variable equal to one for sovereign debt securities issued by certain advanced countries outside the euro area as defined in 2.3.1. As control variables at the security level, we also include the change in the outstanding amount of a security (at market prices) which signifies to what extent investors follow shifts in the market-portfolio. This should be the case under the assumptions of identical investor preferences, no financial frictions, and efficient asset pricing. If investors follow the theoretical predictions of the CAPM, the estimated coefficient should be equal to unity. Moreover, our specification comprises the currency denomination of a security using a binary variable for euro-denominated securities and the original maturity of a security (in log days). In additional estimations, we include the average yield and rating of a security over the PSPP period.

Following recent papers using microdata for the analysis of portfolio rebalancing (e.g. Calvet et al. (2009) or Camanho et al. (2018)), we use fixed effects for the holder country-sector $\left(\alpha_{i}\right)$ and the issuing country-sector $\left(\alpha_{j}\right)$. We further employ bilateral fixed effects $\gamma_{h, s}$ between holder country $h$ and issuer country $s$ to capture all bilateral factors affecting capital flows. This controls for incomplete asset markets and transaction costs in international asset trade as proposed by Martin and Rey (2004) and Okawa and van Wincoop (2012). The bilateral fixed effects thereby absorb gravity variables often used in the empirical literature (e.g. see Galstyan and Lane (2013) for rebalancing during the financial crisis or Boermans and Vermeulen (2016) using microdata on security holdings in the euro area). In all regressions, we cluster the standard errors at the holding country* sector level as the residual might be correlated with country and sector specific demand factors.

Another approach to explain the determinants of international capital flows in the literature encompasses "push" and "pull" factors. Early papers using this concept show evidence that external "push" factors are more important drivers of international capital flows (Calvo et al. (1993), Fernandez-Arias (1996), Chuhan et al. (1998)), while Griffin et al. (2004) argue that domestic "pull" factors are also significant in explaining international transactions. Since these seminal papers, push and pull determinants have received significant attention, especially in the aftermath of the global financial crisis (Fratzscher (2012) and Forbes and Warnock (2012)), and more recently (Cerutti et al. (2017) and McQuade and Schmitz (2019)). In supplementary estimations, we employ the push and pull concept by using bilateral differences of established drivers of capital flows. In particular, we include the following bilateral push and pull factors instead of the bilateral fixed effect $\gamma_{h, s}:(1)$ the

\footnotetext{
${ }^{9}$ Galstyan and Lane (2013) find that during the Global Financial Crisis bilateral cross-border positions were reduced most where pre-crisis bilateral holdings were the largest which they interpret as a "reversion to the mean".
} 
average difference in a news-based policy uncertainty index from Baker et al. $(2016) ;^{10}$ (2) the difference in GDP forecast revisions as a proxy for relative changes in macroeconomic expectations; ${ }^{11}$ (3) the change in the yield differential at the country-level. ${ }^{12}$

Our empirical set-up allows for assessing heterogeneity between different groups of investors by estimating varying $\left(\beta_{d}^{1}, \ldots, \beta_{d}^{k}\right)$ coefficients across sectors or country groups. The advantage of this approach is that it simultaneously estimates the heterogeneous coefficients so that one can directly infer statistical differences between the various coefficients.

\subsection{Empirical implementation}

\subsubsection{Main hypotheses}

Our econometric approach allows for isolating the role of security-specific drivers of euro area capital flows since the launch of the PSPP, for which we specify a set of testable hypotheses:

1. We expect euro area investors to be net sellers of the assets targeted by the Eurosystem under the PSPP and to rebalance into the closest substitutes, in line with the preferred habitat hypothesis. As the price of bonds targeted in the PSPP increased significantly since the start of the programme, with the Eurosystem absorbing sizeable volumes of these securities, investors 'searching for yield' are expected to rebalance into debt securities that allow them to achieve a certain average yield in their portfolios. ${ }^{13}$ Moreover, investors also consider the risk profile of their portfolios which - apart from individual investment strategies - may also be influenced by regulatory constraints, such as risk weights or eligibility for collateral. The security-level of our dataset allows to construct two exogenous variables which enable us to directly investigate our hypothesis, namely PSPP eligibility and PSPP substitute. The former is equal to 1 for those debt securities which are eligible to be purchased by the Eurosystem under the PSPP. These are (i) securities issued by euro area governments or (ii) securities of international or supranational institutions. In addition, the assets need fulfil certain requirements, e.g. a maturity between 2 and 30 years, ratings above credit quality step 3 in

\footnotetext{
${ }^{10}$ This index can be downloaded at http://www.policyuncertainty.com/.It is available for seven euro area countries and we use the index for a European aggregate for the rest of the euro area countries. The index is also available for the 16 most important counterpart countries for euro area investors. We take the average quarterly difference between news-based policy uncertainty (in logs) of the issuer country and the holder country from 2015Q1 to $2016 \mathrm{Q} 4$.

${ }^{11}$ We compute the average difference of revisions in the semiannual forecast (five years ahead) between issuer and holder country from 2015Q1 to 2016Q4. Forecast revisions are calculated from the respective vintages of the IMFs World Economic Outlook.

${ }^{12}$ Using the change in the 10 year government bond yield differential between issuer and holder country between 2014Q4 to 2016Q4. Data are retrieved from the IMFs International Financial Statistics.

${ }^{13}$ By December 2016, the stock of securities purchased by the Euosystem under PSPP summed up to 1.25 trillion EUR.
} 
the Eurosystem's harmonised rating scale (i.e. at least a rating $B B B$ - from Standard\&Poor's or Fitch, $B B B L$ from DBRS, or Baa3 from Moody's), and the yield to maturity has to be above the deposit facility rate, which was equal to -20bp at the time of the launch of the programme in January 2015. ${ }^{14}$ The dummy variable PSPP substitute equals 1 for securities issued by the public sector in non-euro area advanced economies which otherwise fulfil all the requirements of the PSPP, e.g. a 10-year United States (US) treasury bond. ${ }^{15}$ Hence, we do not impose any priors on the definition of PSPP substitutes, but use the exogenously-defined characteristics of PSPP-eligible assets at the security level to test whether there has been a shift from eligible (euro area) assets to assets with the same characteristics outside the euro area, which in turn would have important implications for monetary policy spillovers via international capital flows. If this mechanism is at play, we should find a significantly negative coefficient for PSPP eligible and a positive coefficient for PSPP substitute. Figure 3 illustrates that the average yield of PSPP eligible securities started to decline sharply in mid-2014 when the ECB's credit easing packages were announced and in anticipation of the announcement of a QE programme. At the same time a growing yield differential between PSPP eligible bonds and PSPP substitutes emerged, which peaked in early 2015 after the announcement of the PSPP programme. During the period 2015 to 2016, i.e. the period of our analysis, this yield differential remained persistently large.

2. We expect investors to rebalance into securities with longer maturities. As the euro area yield curve shifted downwards and flattened, but did not invert during the APP period (ECB (2017b), De Santis (2016)), we suggest that investors need to buy additional duration risk (in order to compensate for its removal by the central bank) and thus increase the average maturity of their debt securities in order to achieve a certain yield.

3. We expect a weakening of the euro-denomination bias in debt securities. For the period before 2014, Boermans and Vermeulen (2016) show that there is a significant home as well as euro denomination bias in the euro area holdings of debt securities. During the PSPP period, euro area yields declined not only for those debt securities targeted under the PSPP, but also more broadly for euro-denominated debt securities issued by the private sector, in line with the signalling channel associated with QE. In the case of euro area NFCs, yields were also impacted by the Corporate Sector Purchase Programme (CSPP) in the last six months of our period of observation.

\footnotetext{
${ }^{14}$ More detailed information and the full list of eligible international or supranational institutions can be found at https://www.ecb.europa.eu/mopo/implement/omt/html/index.en.html.

${ }^{15}$ These include sovereign debt securities issued by Australia, Canada, Czech Republic, Denmark, Hong Kong, Japan, New Zealand, Norway, Singapore, Sweden, Switzerland, United Kingdom, and the United States
} 
4. More broadly and mirroring hypothesis 3, we expect euro area portfolio shifts towards other foreign debt securities, including securities issued in emerging economies, in line with the risktaking channel. Such rebalancing was observed for US investors following the introduction of QE (Moore et al., 2013). However, if investors want to maintain a certain risk profile, a shift towards debt issued by other advanced economies may be more likely than a rebalancing towards emerging economies' debt. As a number of advanced countries outside the euro area were "ahead of the cycle" during the period analysed, higher yields could be achieved by substituting securities issued by certain euro area sectors (other than the government) with foreign securities of the same sectors.

5. We expect heterogeneity across sectors within the euro area for several reasons.

First, sectors vary in their degree of professionalism with regard to portfolio allocations which implies a larger role for information asymmetries for certain sectors, in particular in changing financial market conditions as observed during the APP period. Second, theory suggests that accommodative monetary policy that boosts the prices of assets held by balance sheetimpaired sectors relaxes their financial constraints and allows them to increase their lending activity Brunnermeier and Sannikov (2016). Different investment behavior can also be due to regulatory restrictions, such as risk weights attached to particular securities (e.g. for sovereign bonds) or eligibility for collateral. Finally, different sectors might manage assets heterogeneously depending on the business models, e.g. due to different restrictions on the liability side of their balance sheet in terms of maturity or currency denomination. Timmer (2018) shows for German financial institutions that cyclical investment behaviour can be explained by differences in sectors' balance sheet structure.

Therefore, we propose the following sector-specific hypotheses:

- Regarding the hypothesis of net sales of PSPP-eligible assets, we expect retail investors, such as households, to be significant sellers of these bonds. For them, there is no regulatory "price" of shifting from these assets to higher yielding "substitutes" abroad. This substitution may happen via investment funds (part of the OFI sector) which has the additional benefit of avoiding direct foreign currency exposure, which is particularly important for sectors that face higher information frictions (such as households). Banks on the other hand may be limited in their ability to sell eligible assets due to their low (zero) risk weight and their frequent use for collateral in repo transactions.

- We expect the rebalancing into longer term maturities to be driven by ICPFs. Domanski et al. (2017) show that the combination of long-term liabilities and risk regulation leads insurance companies and pension funds to hold long-term bonds, in particular when 
interest rates are low. The long-term liabilities are often independent of the state of economy which gives ICPFs more autonomy in their portfolio choice. Thus, when the yield curve shifts downwards, they can buy duration risk by purchasing longer term securities. Banks on the other hand have a need for liquid assets as deposits are easily redeemable.

6. We expect heterogeneity across euro area countries as the euro area sovereign debt crisis exposed significant country-differences in terms of macroeconomic and financial stability within the euro area. Accordingly, Albertazzi et al. (2018) and Koijen et al. (2018) analyse the impact of the PSPP focusing on a potential difference in the transmission between the formerly stressed and the other 'non-stressed' euro area countries. ${ }^{16}$ We hence refine our hypotheses for these country groups:

- Formerly stressed countries might take more advantage of the opportunity to sell eligible assets given their opportunities to rebalance their portfolio towards higher yielding securities at home and abroad. This mechanism is reinforced by the fact that the PSPP led to positive wealth effects which relaxed in particular the financial constraints of formerly stressed countries (in line with Brunnermeier and Sannikov (2016)) as banks in these countries had purchased significant amounts of domestic public debt during the sovereign debt crisis (Altavilla et al., 2017).

- Following a similar argument as for sector heterogeneity, we expect mainly non-stressed countries to be able to rebalance their portfolio towards longer-term securities due to looser financial constraints. Moreover, such rebalancing is further induced by the low yields recorded on domestic debt securities in these countries.

\subsubsection{Extensions of baseline approach}

In order to shed more light on the mechanisms of international portfolio rebalancing, we provide two extensions to our baseline approach: (i) we focus on different time horizons and (ii) we isolate not only the active part of portfolio rebalancing (i.e. net purchases and sales), but also consider passive rebalancing (i.e. changes in holdings due to valuation). In order to grasp time dynamics, we vary the time frame of the analysis. While our baseline approach covers the 8 quarters since the start of the PSPP, we also analyse short term (2 quarters) and medium-term (6 quarters) rebalancing. Most empirical studies on the financial impact of unconventional monetary policies argue that the largest movements in yields take place upon announcement (e.g. see Krishnamurthy and Vissing-Jorgensen (2011) for the US or Altavilla et al. (2016) and De Santis (2016) for the euro area). Therefore, we

\footnotetext{
${ }^{16}$ The group of formerly stressed countries consists of Cyprus, Greece, Italy, Portugal and Spain.
} 
investigate whether portfolio rebalancing occurred instantaneously, or with a time lag, and whether it has been maintained throughout the duration of the programme. Moreover, we test whether our analysis yields different results for the period before the PSPP was launched (2014Q3 and 2014Q4), which includes the ECB's credit easing package of June 2014 and potential anticipation effects for an LSAP in the euro area following the speech of Draghi (2014) at Jackson Hole.

Furthermore, we distinguish the active (i.e. net purchases) and the passive (i.e. valuation changes) channels of portfolio rebalancing. We substitute our dependent variable $\ln \left(\right.$ flow $\left.w_{a, i, j, t}\right)$ with (i) $\Delta \ln \left(\operatorname{stock}_{a, i, j, t}\right)$ which represents the change in the stock of the holding and (ii) $\left[\Delta \ln \left(\operatorname{stock} k_{a, i, j, t}\right)-\right.$ $\ln \left(\right.$ flow $\left.\left._{a, i, j, t}\right)\right]$ which are the passive changes in holdings that are not due to transactions, but due to valuation changes resulting from fluctuations in asset prices. With this, we follow the intuition of Ahmed et al. (2016) who apply this concept to US capital flows targeting EMEs and Bubeck et al. (2017) who implement this idea in an event study analysis for Luxembourg-based mutual funds following ECB monetary policy announcements.

\section{Descriptive evidence on euro area rebalancing during the PSPP period}

We provide descriptive evidence on the 'active' portfolio rebalancing (i.e. in terms of net transactions) of euro area investors since the launch of the PSPP. By constructing these statistics from the security-level SHSS dataset we are able to provide additional insights compared to analysis which rests entirely on aggregate statistics such as the balance of payments statistics presented in Figures 1 and 2 (see also Bergant and Schmitz (2019)).

\subsection{Debt securities}

Starting with transactions in debt securities, Figure 4 shows that euro area investors were net sellers of securities eligible to be bought by the Eurosystem under the PSPP in the period 2015Q1-2016Q4, which is in line with our hypothesis 1. In fact, more than EUR 250 billion PSPP eligible securities were sold in net terms by euro area investors in the period 2015Q1-2016Q4. However, even larger net sales by euro area residents were recorded for other debt securities issued in the euro area, of which the largest share was those issued by euro area banks. These net sales can be mainly attributed to negative net issuance of bonds by the euro area banking sector and spillovers from the PSPP under the signalling channel. ${ }^{17}$ Thereby, a commitment by the central bank to keep short-term rates low

\footnotetext{
${ }^{17}$ Net sales/redemptions of debt securities issued by MFIs may reflect partly negative net issuance due to the broadbased deleveraging in the euro area banking sector as well as funding substitution towards the Eurosystem's targeted longer-term refinancing operations. Under this open market operation, the ECB had offered long-term funding at
} 
for a considerable period of time has a negative effect on the yields of all debt securities - including those that are not PSPP eligible - via the expectations hypothesis of interest rates (Krishnamurthy and Vissing-Jorgensen, 2011).

Net sales of euro area debt instruments were mirrored in sizeable net purchases of foreign debt securities by euro area residents, as can be expected under the signalling channel to the extent that it results in an increase of the interest rate differential. In line with hypothesis number 1, we observe in particular significant net purchases (around EUR 350 billion) of foreign sovereign debt securities, of which around $40 \%$ qualify as the closest substitutes for PSPP eligible assets, consistent with the preferred habitat hypothesis. Moreover, net purchases of foreign debt securities issued by the private sector were even slightly higher, thus closely matching the net sales of private euro area area debt securities.

Figure 5 shows which sectors drove these overall patterns: MFIs, households and OFIs (mainly investment funds) accounted for the largest net sales of PSPP eligible and other euro area debt securities, while insurance companies and pension funds (ICPFs) were net buyers of both types of euro area debt securities. OFIs bought the largest amounts of PSPP substitutes as well as foreign debt securities in general, followed by MFIs and ICPFs. In terms of investors' country of residence, the rebalancing towards non-euro area debt securities was driven by the financial centres Ireland and Luxembourg - hosting many of the euro area investment funds - as well as to a lesser extent Germany and France. Spanish investors sold the largest amount of PSPP eligible securities, followed by the Netherlands, Germany, France, and Italy (see Figure 6). Italy stands out as resident investors were the largest net sellers of other euro area debt securities, followed by Germany and France.

\subsection{Beyond debt securities}

Figure 7 also includes equity securities, i.e. investment fund shares and listed shares, to investigate the transmission of quantitative easing from targeted securities towards other instruments. In our analysis, securities are split into those issued by euro area residents and foreign securities in Figures 7-9. Euro area investors were overall net sellers of euro area debt securities and mainly rebalanced their portfolios towards euro area investment fund shares, debt securities issued outside the euro area, and to a lesser extent to euro area and foreign listed shares. Figure 8 provides important insights into the sectoral 'flow of funds' behind these aggregate flows: the net sales of euro area debt securities were driven by MFIs and households, while ICPFs, households and OFIs bought the largest amounts of euro area investment fund shares as shown on the left hand side of Figure 8. On the right hand side, we observe that OFIs were by far the largest net buyers of foreign debt securities, followed by MFIs and ICPFs. The increased investment of OFIs in foreign debt

attractive conditions to banks since June 2014 . 
instruments goes in hand with increased funding that OFIs receive from other euro area investors, such as households. This suggests that MFIs and to a lesser extent also ICPFs were buying foreign debt securities directly, while in particular households channelled their investments into overseas debt securities via investment funds. Figure 9 shows that the largest net purchases of euro area investment fund shares originated from Germany, Italy, Spain and France. ${ }^{18}$

Figure 10 sheds more light on euro area flows into investment fund shares. Based on security-level information from the ESCB's Centralised Securities Data Base (CSDB), we differentiate investment funds by their main investment mandate. The graph shows that the largest net inflows by euro area residents went into 'mixed' investment funds, followed by investment funds with explicit mandates to invest in bonds. Particularly households and ICPFs were large net buyers of 'mixed' funds, while for OFIs bond funds constituted the largest type. Aggregate ECB investment fund statistics in turn show that euro area investment funds mainly bought shares of other investment funds, debt securities and listed shares in our period of analysis. Combining the evidence contained in Figures 8 and 10 confirms that at the end of the investment chain, OFIs channelled large funds towards the acquisition of non-euro area debt securities.

\subsection{Geography, currency, and maturity}

In terms of geographical composition, Figure 11 shows that euro area residents were net sellers of debt securities issued in their home countries, while they invested heavily into US debt securities, followed by those issued in the United Kingdom (UK) and in the residual country group "rest of the world". Large net purchases of US debt securities can be explained by the substantial yield differentials between the euro area and the US since the start of the start of the ECB's unconventional monetary policy. Indeed, the largest net purchases of debt securities by euro area residents were recorded for those issued by the US government sector, followed by US NFCs (see also Bergant and Schmitz (2019)). MFIs and households in particular sold domestic securities, while OFIs' net purchases focused almost entirely on extra-euro area debt securities, with the US and UK accounting for the largest shares. On the right hand side of Figure 11, we see that the majority of net equity purchases consisted of those issued by domestic and other euro area residents, which mainly reflect investment fund shares.

The geographic composition is mirrored in changes in currency exposures. Figure 12 shows sizeable net sales of euro-denominated debt securities - in line with our third hypothesis, suggesting a reduced euro preference in debt securities. Furthermore, one can observe an increase in the exposure to debt securities denominated in US dollars, and also British pounds, while net purchases

\footnotetext{
${ }^{18}$ The large purchases of euro area investment fund shares were driven by ICPFs in Germany and France and by households in Italy and Spain. In turn, Luxembourg-based OFIs accounted for $86 \%$ of all euro area OFI net purchases of extra-euro area government bonds.
} 
of equities were to a large extent euro-denominated. Strikingly, all sectors were net buyers of US dollar-denominated debt, with more than half of net purchases being conducted by OFIs as shown in Figure 13. ICPFs and to a much smaller extent also OFIs were net buyers of euro-denominated debt securities.

With regard to our second hypothesis, i.e. that under the duration risk channel investors will rebalance their portfolio to longer-term securities, Figure 14 reveals that the majority of net purchases of debt securities fell within the bucket of assets with an original maturity of more than 10 years. Moreover, the vast majority of net sales consisted of assets with a maturity between 2 to 5 years after origination. Figure 15 shows that the large net purchases of assets with a minimum maturity of 10 years is driven by ICPFs and OFIs. In particular for ICPFs, these purchases are likely due to their need to match longer-term liabilities with longer-term assets. The large net sales of 2-5 year securities were - just like the sales of PSPP eligible assets - mainly driven by MFIs and households.

Summing up, we find strong support for our hypotheses by looking at descriptive evidence. Euro area investors rebalanced their portfolios from euro area debt securities to foreign debt. As large net purchases of euro area investment fund shares were also recorded, the acquisition of foreign debt appears to have been partly channelled - in particular for households - through mutual funds. Overall, this confirms that investors were "searching for yield" and investing partly in the "closest substitutes" to securities targeted under the PSPP, i.e. sovereign debt of advanced countries outside the euro area. We also find evidence for portfolio rebalancing towards longer-term maturities as more than $50 \%$ of net purchases consisted of securities with a maturity exceeding 10 years. Moreover, we also observe strong sector heterogeneity as for instance ICPFs were net buyers of PSPP eligible assets and other euro area debt securities since the launch of the PSPP.

\section{Econometric evidence on euro area rebalancing during the PSPP}

\subsection{Overall results}

Table 1 presents the overall estimation results for equation (3) focusing on euro area country-sectors' net transactions in individual debt securities, summed over the PSPP period 2015Q1 to 2016Q4. We observe in column (1) that the PSPP eligibility variable is significant with a negative sign. This confirms hypothesis number 1 , i.e. that euro area investors significantly rebalanced their portfolios away from those individual securities targeted under the PSPP, controlling for a vast array of security-specific as well as country and sector specific factors. In column (2), we add the PSPP substitute variable which turns out to be positive, though insignificant. Our descriptive evidence suggests that this might be because euro area investors gained exposure to PSPP substitutes through 
an indirect channel, i.e. via net purchases of investment fund shares, which we will analyse in the next subsection.

Across Table 1, we also confirm hypothesis number 2, as the coefficient on the original maturity variable is significantly positive. This indicates that euro area investors were net buyers of relatively more long-term securities which might be driven by the general decrease in yields, enticing investors to shift to longer-term securities in order to achieve a certain yield within one asset class. The euro currency denomination variable turns out insignificant, which is in line with hypothesis 3 and suggests an increased rebalancing towards foreign-currency denominated debt securities, especially considering that Boermans and Vermeulen (2016) find evidence for a strong preference for holdings of euro-denominated debt securities in the pre-APP period.

We further obtain a negative coefficient for the pre-PSPP holding variable, confirming the "mean reversion" found by Galstyan and Lane (2013). This implies that investors sold (bought) assets that they held relatively large (small) amounts of before the programme started, i.e. in 2014Q4. For the change in the outstanding amount (at market prices) over the PSPP period, we observe a significantly positive coefficient of around 0.5 which is in line with the predictions of the CAPM as investors were partly following developments of the overall market portfolio. ${ }^{19}$

In columns (3) to (8), we perform various modifications to the baseline results. In column 3 , we exclude all domestic securities (i.e. the net purchases of those securities issued in an investor's country of residence), which shows similar results, but a slightly lower coefficient on PSPP eligibility. This indicates that euro area investors were selling in particular those securities to the Eurosystem that were issued by governments of their country of residence. In column (4), we exclude all observations that feature Ireland and Luxembourg - both as investor or issuing countries - due to their financial centre role in the euro area. The results show a more negative coefficient on PSPP eligibility and a larger coefficient for the maturity variable. In column (5), we include only longterm debt securities (i.e. those with an original maturity of more than 12 months), which delivers very similar results, likely driven by their large share in overall debt securities (around $95 \%$ in our sample).

Next, we explore evidence with regard to the question whether the PSPP has led to increased risk-taking by euro area investors in terms of purchases of debt securities. In column (6), we introduce a dummy variable that takes the value one if the average yield of a security over the PSPP period was within the highest decile of yields. The variable turns out to be insignificant, and remains insignificant if we replace it - in unreported regressions available upon request - with a dummy for the upper $25 \%$ of yields or with the yield itself. In column (7), we define a dummy variable

\footnotetext{
${ }^{19}$ Boermans and Vermeulen (2016) find similar (or lower) coefficients for cross-sectional holdings before APP. The authors suggest that an explanation for these relatively low values - compared to a theoretical coefficient of 1 derived from the CAPM - might be that individual bonds may have several substitutes.
} 
for those securities rated within the worst rating category (out of four standardised categories in the Eurosystem's harmonised rating scale). This corresponds to a credit rating of $B B+$ and below for Standard \& Poor's and Fitch. ${ }^{20}$ As this variable also turns out to be insignificant, we do not observe any evidence that euro area investors were taking significantly more risk by investing into lower-rated, high-yield debt securities. ${ }^{21}$

Finally in column (8), we use a set of push and pull variables described in Section 2.2, rather than country-pair dummies, which leaves our results intact. Using the entire sample, the only significant variable is the average difference in news-based policy uncertainty measured following Baker et al. (2016). Euro area investors show significantly lower net purchases of debt securities issued by economies in which economic policy uncertainty is higher than in the investors' euro area country of residence. When we restrict the sample to securities issued by countries outside the euro area, the bilateral yield differential turns significantly positive (in unreported estimations). ${ }^{22}$ We thus find that euro are investors bought larger amounts of debt securities issued by non-euro area countries with higher aggregate yields during the PSPP programme, in line with a push-pull framework.

\subsection{Sector heterogeneity}

In Table 2, we report our main specification but estimated with heterogeneous coefficients across sectors. As put forward in the sector-specific hypotheses in Section 2.3.1, we expect heterogeneity across sectors due to different regulatory restrictions, asset management strategies, and sophistication regarding information on financial market developments. This heterogeneity is clearly reflected in our results, especially when considering the coefficients which respond to our main hypotheses.

In particular, with regard to hypothesis 1 , we find a significant negative coefficient on PSPP eligibility for OFIs, while at the same time OFIs are found to invest in PSPP substitutes, in line with preferred habitat motives. ${ }^{23}$ Combining this with our descriptive evidence (see Figures 7-9) and taking into account the "flow of funds" within the euro area, these investment patterns reflect to a large extent the "channelling" of the underlying ultimate investors' preferences via investment funds. This also implies that the insignificance of the closest substitute in Table 1 is likely to be driven by the fact that other sectors are channelling their investments into closest substitutes via

\footnotetext{
${ }^{20}$ The worst rating across the four major rating agencies is used.

${ }^{21}$ Our sample size shrinks by more than $50 \%$ in the estimations displayed in columns (6) and (7) due to limited data availability. In further unreported estimations, we include a dummy variable controlling for securities maturing during the PSPP period. As anticipated, this variable is significant with a negative sign, but leaves our main results unchanged.

${ }^{22}$ These results are available upon request.

${ }^{23}$ In unreported estimations, we find evidence that OFIs rebalanced even more strongly away from those PSPP eligible securities which exhibited average negative yields during the PSPP period.
} 
mutual funds rather than investing directly into foreign sovereign debt. In line with this mechanism, we find that non-financial corporations and households were significant net sellers of PSPP eligible assets and euro denominated assets more generally.

For MFIs on the other hand, the PSPP eligible coefficient is insignificant, while the one for eurodenomination is significantly positive. This reflects banks' incentive to hold PSPP eligible assets because of the zero risk weight attached to them and due to their role as collateral in monetary policy operations. The fact that the PSPP eligibility coefficient is not significant for MFIs, even though Figure 5 showed that MFIs were the sector with the largest net sales of PSPP securities, may be puzzling at first glance. However, it is important to note that the regression analysis controls for a vast array of factors, such as the pre-PSPP level of PSPP-eligible assets which were the largest for MFIs. Moreover, the regression results are further underpinned by the fact that MFIs' net sales of other euro area debt securities were three times larger than those of PSPP eligible debt securities (Figure 5).

Consistent with our sector hypothesis, we also observe a strong preference for net purchases of longer-term securities for ICPFs, in line with the duration risk and preferred habitat channels. This is particularly large for this sector, followed by NFCs and households. Finally, the negative coefficient on pre-PSPP holdings and the positive sign on changes in the outstanding amounts of a security remain significant across all sectors, confirming their general validity.

\subsection{Geography}

To answer the question to what extent euro area investors' portfolio shifted towards foreign bonds other than closest PSPP substitutes, we add additional variables to our baseline estimation that track which country-sectors received relatively larger inflows from euro area investors during the PSPP period. This exercise also serves as a robustness test with regard to our key findings on PSPP eligibility and substitutes. ${ }^{24}$

We split the geography of euro area investors' capital flows into issuing sectors from three country groups: euro area (EA), other advanced (ADV) and emerging (EME) economies. ${ }^{25}$

In Table 3, we observe that PSPP eligibility remains significant overall (column 1), while net investment by euro are OFIs into closest substitutes remains significant, too. Our analysis further

\footnotetext{
${ }^{24}$ Since we include additional dummy variables for securities issued by a number of country-sectors we test that our baseline findings are not resulting from an omitted variable bias. Specifically, to avoid multicollinearity problems in the presence of issuer-sector fixed effects, we define the country-group-sector dummies for long-term debt securities.

${ }^{25}$ Countries classified as advanced include Australia, Canada, Czech Republic, Denmark, Hong Kong, Japan, New Zealand, Norway, Singapore, Sweden, Switzerland, United Kingdom, and the United States. Our definition of EMEs - which is broadly consistent with the IMF's definition - includes Argentina, Bangladesh, Brazil, Chile, China, Columbia, Indonesia, Malaysia, Mexico, Pakistan, Peru, Philippines, Russia, South Africa, South Korea, Thailand, Turkey, Uruguay and Venezuela.
} 
reveals several interesting patterns with regard to securities issued by euro area residents: we find significant net purchases of debt securities issued by OFIs (driven by the household and NFC sectors). These securities are largely bonds issued by financial intermediaries that are linked to euro area NFCs (or MFIs) as well as entities engaged in securitisation.

Moreover, we observe that all euro area sectors invested significantly in bonds issued by banks and OFIs resident in advanced countries outside the euro area, while euro area ICPFs and households also invested to a significant extent in bonds issues by advanced economies' NFCs. These results show that euro area investors did not only rebalance into closest substitutes, but conducted broadbased purchases of debt securities issued in advanced economies. This is in line with the evidence presented by Ammer et al. (2018) who find that non-US investors faced with low interest rates at home rebalanced towards riskier US corporate bonds, in line with the risk-taking channel.

We also investigate whether the PSPP has led to increased investment into emerging market debt securities as observed for US investors following the introduction of QE (Moore et al., 2013). In line with (Coeure, 2017), we do not find evidence of broad-based euro area net purchases of relatively more risky - debt securities issued by EMEs. However, we observe significant net buying of EME sovereign bonds by euro area MFIs.

Overall, our results show that euro area investor's shift towards foreign debt was broad-based across sectors, but mainly targeted at other advanced economies, in contrast to the patterns observed for US investors following QE.

\subsection{Country heterogeneity}

Table 4 reports the estimation results with heterogeneous coefficients across the formerly stressed and non-stressed euro area country groups. ${ }^{26}$ Confirming our hypotheses, we observe that both country groups were significant net sellers of PSPP eligible securities. However, the coefficient is almost three times as large for formerly stressed countries indicating that investors from such countries had a larger propensity to rebalance away from PSPP-eligible assets. As financial constraints were more binding in the formerly stressed countries, the finding suggests that positive wealth effects enticed investors from these countries to realise capital gains made on PSPP eligible securities. These capital gains were particularly sizable for banks in formerly stressed countries as they had purchased significant amounts of domestic public debt during the sovereign debt crisis reflecting "moral suasion" by governments as well as "carry trade" motives as these banks used cheap funding by the Eurosystem to invest in high-yielding sovereign debt (Altavilla et al., 2017). Our findings are also in line with Albertazzi et al. (2018) who report evidence of portfolio rebalancing towards

\footnotetext{
${ }^{26}$ The group of formerly stressed countries consists of Cyprus, Greece, Italy, Portugal and Spain. We exclude Ireland and Luxembourg from these estimations due to their large financial intermediation role.
} 
riskier securities in the formerly stressed economies where risk-premia remained relatively higher.

As regards our second hypothesis, only investors of non-stressed countries were significant net buyers of longer-term maturity bonds, which is likely driven by the fact that yields were lower in these countries, resulting in a stronger pressure to shift into longer-term maturities, compounded by looser financial constraints that allow investors to expand their investment horizon.

\subsection{Time dynamics}

Next, we consider the time dynamics in euro area portfolio rebalancing for debt securities during the PSPP period in Table 5. In column (1), we analyse the period before the announcement of the PSPP (2014Q3-2014Q4) which includes the implementation of the ECB's credit easing package of June 2014 to account for potential anticipation effects for an LSAP in the euro area following the speech of Draghi (2014) at Jackson Hole. In contrast to our benchmark results for the whole PSPP period (column 4), euro area investors were significant net buyers of PSPP eligible assets in the two quarters before the programme was announced, which hints at the game-changing nature of the PSPP for euro area financial flows. The net purchases before the PSPP were likely driven by the growing expectation of an impending quantitative easing programme in the euro area, suggesting that investors were betting on valuation gains in the run-up to the PSPP. This is in line with Lemke and Werner (2017) who argue that the decline in yields of German sovereign debt before the PSPP points to a portfolio rebalancing towards eligible assets in anticipation of the programme. ${ }^{27}$

Column (2) considers the determinants of 'short-term' rebalancing (in the two quarters since the start of the PSPP, 2015Q1-2015Q2), for which we observe a significantly negative coefficient on PSPP eligible assets and euro-denominated debt securities. Thus, already immediately after the launch of the programme, euro area investors started to rebalance in line with our hypotheses. Moreover, for net purchases in this short-term period, we find a relatively strong positive coefficient on changes in the outstanding amount of a security - suggesting that investors generally follow the market portfolio - and a less pronounced reversion to the mean.

In the third column we analyse net purchases cumulated over the medium-term (6 quarters), in which the negative coefficients on PSPP eligibility and euro-denomination turn out larger than in the short term, suggesting that in this period the rebalancing forces of euro area investors were the strongest. Importantly, net sales of euro denominated assets were only significant in the short and medium term, but not in column 4, which might reflect the strong announcement effects of the programme (Georgiadis and Graeb, 2016). Moreover, the need of certain sectors to hold euro-denominated securities might have prevented a protracted rebalancing away from those securities. The coefficient on the original maturity of a security exhibits a larger positive sign over

\footnotetext{
${ }^{27}$ Interestingly, this period is also associated with (marginally) significant net purchases of PSPP substitutes.
} 
time, suggesting that investors gradually switched to longer-term maturities, likely reflecting the extended low yield environment.

To explore the time dynamics across sectors we zoom in on the PSPP eligibility coefficients for each sector (Table 6). The phenomenon of "loading up" eligible assets before the start of the programme is driven by investment funds (column 1), suggesting that these relatively more sophisticated investors were speculating on valuation gains before the start of PSPP. In the short term (column 2), MFIs and household exhibit significant negative coefficients. Thus, while MFIs do not appear as significant net sellers of PSPP eligible assets over the entire period considered, this was different in the early days of the programme. The observed strongest rebalancing in the medium term (6 quarters, column 3) is driven by households, OFIs and NFCs, which also holds true for the baseline period in column 4 .

\subsection{Active vs. passive rebalancing}

Motivated by the theoretical model of Tille and van Wincoop (2010), we shed light on the different dynamics of the active (i.e. net purchases) and the passive channels of portfolio rebalancing. ${ }^{28}$

In Table 7 column (1), our dependent variables are, respectively, the cumulative net purchases of debt securities over the period 2015Q1-2016Q4 $\ln \left(\right.$ flow $\left._{a, h, s}\right)$, the corresponding change in holdings between 2014q4 and 2016q4 $\Delta \ln \left(\right.$ stock $\left._{a, h, s}\right)$ in column (3) and in column (2) the difference between the latter and the former, i.e. $\left[\Delta \ln \left(\operatorname{stock}_{a, h, s}\right)-\ln \left(f l o w_{a, h, s}\right)\right]$ which correspond to valuation changes. While running a full regression analysis, we zoom in on hypothesis 1 and observe - as in our baseline estimation - a negative coefficient on PSPP eligibility for transactions. Moreover, we obtain a positive coefficient in the 'passive' rebalancing estimation implying that euro area investors recorded significant positive valuation gains in PSPP eligible assets relative to all other debt securities held during this period. For changes in overall holdings, we do not find a significant coefficient for PSPP eligible asset during our period of analysis (column 3). This emphasises the importance of analysing actual transactions rather than proxying these with changes in holdings.

Across sectors, the second panel of Table 7 shows that the observed aggregate patterns are driven by OFIs, MFIs and households, albeit to varying degrees. Significant net sales and positive valuation gains in PSPP-eligible securities are found for all three sectors, while a significant (and negative) coefficient in the overall change in holdings estimation is only obtained for households. ${ }^{29}$

\footnotetext{
${ }^{28} \mathrm{~A}$ subsample is used as this analysis is only feasible for those securities that were held by a certain sector both before the launch of the PSPP (i.e. at the end of 2014Q4) and at the end of our sample period (i.e. 2016Q4) and for which holdings as well as transactions were reported. This restriction is necessary as in case a security is only held at the beginning of the sample period or only at the end of the period, no change in the market value of the holdings ("passive rebalancing") of this security can be computed.

${ }^{29}$ In this subsample, significant (at the $10 \%$ level) net sales of PSPP-eligble securities are recorded for MFIs.
} 
Descriptive evidence on the aggregate volumes of the active and passive rebalancing components by sector (Figure 16) highlights that sizeable valuation gains in PSPP eligible assets were achieved by ICPFs, i.e. the sector that continued to be a net buyer of these assets, while MFIs and households recorded large net sales of these assets and only small valuation gains during the PSPP period. OFIs on the other hand, generated more sizeable valuation gains, while selling PSPP eligible assets, thereby offsetting part of the net sales.

The results in this subsection highlight that the active (i.e. net purchases) and passive channels of portfolio rebalancing in PSPP eligible securities were working in opposite directions during the PSPP period. Thereby, overall net sales of these securities by euro area investors were only partly offset by positive valuation gains.

\section{Conclusion}

Our paper is - to the best of our knowledge - the first to analyse international capital flows (i.e. net purchases or net sales) at the security level. Using a model of these flows, we are able to test several hypotheses with regard to the impact of the APP on portfolio rebalancing, for which we emphasize significant sector and country heterogeneity within the euro area:

First, we expected euro area investors to be net sellers of the assets targeted by the Eurosystem under the PSPP and to rebalance into "closest substitutes." Descriptively, we observe that euro area investors rebalanced their portfolios from domestic and other euro area debt securities towards foreign debt. Our regression analysis confirms that euro area investors significantly rebalanced away from individual securities targeted under the PSPP. This rebalancing was particularly strong during the first six quarters of the programme. In particular, OFIs show rebalancing as they invested significantly in assets defined as closest substitute to the PSPP-eligible securities, in line with preferred habitat motives, underlining the impact of the PSPP on international capital flows. Moreover, we find that NFCs and households were significant net sellers of euro denominated assets and especially PSPP eligible assets. Households in particular made use of investment funds to gain exposure to foreign sovereign debt. MFIs and ICPFs on the other hand are not found to be significant net sellers of PSPP eligible assets and MFIs were significant net buyers of euro denominated securities, reflecting regulatory and balance sheet management reasons. We find that both the formerly stressed and non-stressed euro area countries were significant net sellers of PSPP eligible securities, but the impact was larger for formerly stressed countries. Second, we expected investors to rebalance into securities with longer maturities, for which we find significant evidence as euro area investors were net buyers of relatively more long-term securities. This was particularly pronounced for ICPFs, in line with the duration risk and preferred habitat channels. Overall, net 
purchases of securities with a maturity exceeding 10 years made up $50 \%$ of net debt purchases.

Third, we expected a weakening of the euro-denomination bias in debt securities. Indeed, we observe overall evidence for a rebalancing away from euro-denominated debt securities, in line with the signalling channel associated with QE. Our results show that euro area investor's shift towards foreign debt was broad-based across sectors, thereby creating global spillovers from the ECB's policies, but mainly targeted at other advanced economies, in contrast to the patterns observed for US investors following QE.

We also investigated potential anticipation effects of the PSPP following Draghi (2014) speech at Jackson Hole and find that euro area investors were indeed net buyers of PSPP eligible securities in anticipation of the programme.

Finally, as our dataset also comprises the holdings of individual securities, we are able to decompose overall portfolio rebalancing of euro area investors into 'active' (i.e. capital flows) and 'passive' components (i.e. valuation changes due to fluctuations in asset prices). This analysis reveals the importance of analysing actual transactions rather than proxying these with changes in holdings. Moreover, we find that active net sales of PSPP-eligible securities by euro area investors were only partly offset by positive capital gains. 


\section{References}

Ahmed, S., S. E. Curcuru, F. E. Warnock, and A. Zlate (2016): "Decomposing International Portfolio Flows," Tech. rep., Prepared for the SUERF/PSE/CEPII Conference Rethinking Capital Controls and Capital Flows.

Albertazzi, U., B. Becker, And M. Boucinha (2018): "Portfolio Rebalancing and the Transmission of Large-Scale Asset Programs: Evidence from the Euro Area," ECB Working Paper 2125 .

Altavilla, C., F. Canova, And M. Ciccarelli (2016): "Mending the broken link: heterogeneous bank lending and monetary policy pass-through," ECB Working Papers 1978.

Altavilla, C., G. Carboni, and R. Motto (2015): "Asset purchase programmes and financial markets: lessons from the euro area," ECB Working Paper Series 1864.

Altavilla, C., S. Simonelli, And M. Pagano (2017): "Bank Exposures and Sovereign Stress Transmission," Review of Finance, 21, 2103-2139.

Ammer, J., S. Claessens, A. M. Tabova, and C. Wroblewski (2018): "Searching for Yield Abroad : Risk-Taking Through Foreign Investment in U.S. Bonds," International Finance Discussion Papers 1224, Board of Governors of the Federal Reserve System.

Andrade, P., J. Breckenfelder, F. D. Fiore, P. Karadi, and O. Tristani (2016): "The ECB's asset purchase programme: an early assessment," ECB Working Paper 1956.

Baker, S. R., N. Bloom, And S. J. Davis (2016): "Measuring Economic Policy Uncertainty," The Quarterly Journal of Economics, 131, 1593-1636.

Bergant, K. And M. Schmitz (2019): "International financial flows and the Eurosystem's asset purchase programme: evidence from b.o.p and security by security data," in Are post-crisis statistical initiatives completed?, ed. by B. for International Settlements, Bank for International Settlements, vol. 49 of IFC Bulletins chapters.

Boermans, M. and R. Vermeulen (2016): "International investment positions revisited: Investor heterogeneity and individual security characteristics," DNB Working Papers 531, Netherlands Central Bank, Research Department.

- (2018): "Quantitative easing and preferred habitat investors in the euro area bond market," DNB Working Papers 586, Netherlands Central Bank, Research Department. 
Brunnermeier, M. K. And Y. Sannikov (2016): "The I Theory of Money," Working Paper 22533, National Bureau of Economic Research.

Bua, G. And P. G. Dunne (2019): "The Portfolio Rebalancing Effects of the ECB's Asset Purchase Programme," International Journal of Central Banking, 15, 1-46.

Bubeck, J., M. M. Habib, And S. Manganelli (2017): "The Portfolio of Euro Area Fund Investors and ECB Monetary Policy Announcements," ECB Working Paper 2116.

Calvet, L. E., J. Y. Campbell, and P. Sodini (2009): "Fight or Flight? Portfolio Rebalancing by Individual Investors," Tech. Rep. 1.

Calvo, G. A., L. Leiderman, and C. M. Reinhart (1993): "Capital Inflows and Real Exchange Rate Appreciation in Latin America: The Role of External Factors," IMF Staff Papers, 40, 108151.

(1996): "Inflows of Capital to Developing Countries in the 1990s," Journal of Economic Perspectives, 10, 123-139.

Camanho, N., H. Hau, And H. Rey (2018): "Global Portfolio Rebalancing and Exchange Rates," NBER Working Papers 24320.

Cerutti, E. M., S. Clafessens, And A. K. Rose (2017): "How Important is the Global Financial Cycle? Evidence from Capital Flows," IMF Working Papers 17/193, International Monetary Fund.

Chari, A., K. D. Stedman, and C. Lundblad (2017): "Taper Tantrums: QE, its Aftermath and Emerging Market Capital Flows," NBER Working Papers 23474, National Bureau of Economic Research, Inc.

Chuhan, P., S. Claessens, and N. Mamingi (1998): "Equity and bond flows to Latin America and Asia: the role of global and country factors," Journal of Development Economics, 55, 439463.

Coeure, B. (2017): "The international dimension of the ECB's asset purchase programme," Speech by Benoit Coeure at the Foreign Exchange Contact Group meeting, 11 July 2017.

De Santis, R. A. (2016): "Impact of the asset purchase programme on euro area government bond yields using market news," ECB Working Paper 1939.

Domanski, D., H. S. Shin, And V. Sushko (2017): "The Hunt for Duration: Not Waving but Drowning?" IMF Economic Review, 65, 113-153. 
Draghi, M. (2014): "Unemployment in the euro area," Speech by Mario Draghi, President of the ECB, Annual central bank symposium in Jackson Hole, 22 August 2014.

ECB (2017a): "Analysing euro area net portfolio investment outflows," Economic Bulletin 2.

(2017b): "Impact of the ECBs non-standard measures on financing conditions: taking stock of recent evidence," Economic Bulletin 2.

— (2017c): "Who holds what? New information on securities holdings," Economic Bulletin 4.

Eisenschmidt, J., D. Kedan, M. Schmitz, R. Adalid, and P. Papsdorf (2017): "The Eurosystems asset purchase programme and TARGET balances," ECB Occasional Paper 196.

Falagiarda, M., P. McQuade, And M. Tirpak (2015): "Spillovers from the ECB's nonstandard monetary policies on non-euro area EU countries: evidence from an event-study analysis," Working Paper 1869, European Central Bank.

Fernandez-Arias, E. (1996): "The new wave of private capital inflows: Push or pull?" Journal of Development Economics, 48, 389-418.

Forbes, K. J. And F. E. WArnock (2012): "Capital flow waves: Surges, stops, flight, and retrenchment," Journal of International Economics, 88, 235-251.

Fratzscher, M. (2012): "Capital flows, push versus pull factors and the global financial crisis," Journal of International Economics, 88, 341-356.

Galstyan, V. And P. R. LAne (2013): "Bilateral portfolio dynamics during the global financial crisis," European Economic Review, 57, 63-74.

Georgiadis, G. And J. Graeb (2016): "Global financial market impact of the announcement of the ECB's asset purchase programme," Journal of Financial Stability, 26, 257-265.

Griffin, J. M., F. Nardari, and R. M. Stulz (2004): "Are Daily Cross-Border Equity Flows Pushed or Pulled?" The Review of Economics and Statistics, 86, 641-657.

Hau, H., N. Camanho, and H. Rey (2017): "Global Portfolio Rebalancing under the Microscope," Sfi working paper.

Heipertz, J., R. Ranciere, And N. Valla (2016): "Domestic and international sectoral portfolios: Network structure and balance sheet effects," mimeo.

Koijen, R. S. J., F. Koulischer, B. Nguyen, And M. Yogo (2018): "Inspecting the Mechanism of Quantitative Easing in the Euro Area," Banque de France Working Paper. 
Krishnamurthy, A. And A. Vissing-Jorgensen (2011): "The Effects of Quantitative Easing on Interest Rates: Channels and Implications for Policy," Brookings Papers on Economic Activity.

Lane, P. R. (2015): "Risk Exposures in International and Sectoral Balance Sheet Data," World Economics, 16, 55-76.

Lemke, W. And T. Werner (2017): "Dissecting long-term Bund yields in the run-up to the ECB's Public Sector Purchase Programme," ECB Working Papers 2106.

Levy Yeyati, E., U. Panizza, And E. Stein (2007): "The cyclical nature of North-South FDI flows," Journal of International Money and Finance, 26, 104-130.

Martin, P. And H. Rey (2004): "Financial super-markets: size matters for asset trade," Journal of International Economics, 64, 335 - 361.

McQuade, P. And M. Schmitz (2019): "America First? A US-centric view of global capital flows," Working Paper Series 2238, European Central Bank.

Moore, J., S. Nam, M. Suh, And A. Tepper (2013): "Estimating the impacts of U.S. LSAPs on emerging market economies local currency bond markets," Tech. rep.

NeELy, C. J. (2010): "The large scale asset purchases had large international effects," Tech. rep.

OKaWA, Y. AND E. VAN WincoOP (2012): "Gravity in International Finance," Journal of International Economics, 87, 205-215.

Tille, C. And E. van Wincoop (2010): "International capital flows," Journal of International Economics, 80, 157 - 175.

Timmer, Y. (2018): "Cyclical Investment Behavior across Financial Institutions," Journal of Financial Economics.

Vayanos, D. And J.-L. Vila (2009): "A Preferred-Habitat Model of the Term Structure of Interest Rates," NBER Working Papers 15487. 


\section{$6 \quad$ Figures}

Figure 1: Breakdown of euro area net portfolio investment flows

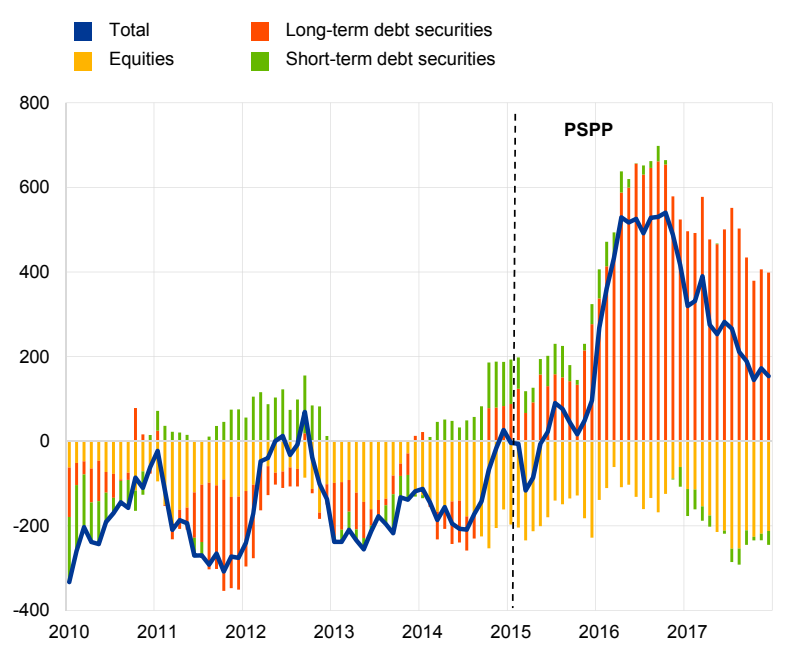

Source: ECB.

Notes: A positive (negative) number indicates net outflows (inflows) from (into) the euro area. Equity includes investment fund shares. Last observation is December 2017. 12-month cumulative sums in bn EUR.

Figure 2: Breakdown of euro area portfolio investment outflows

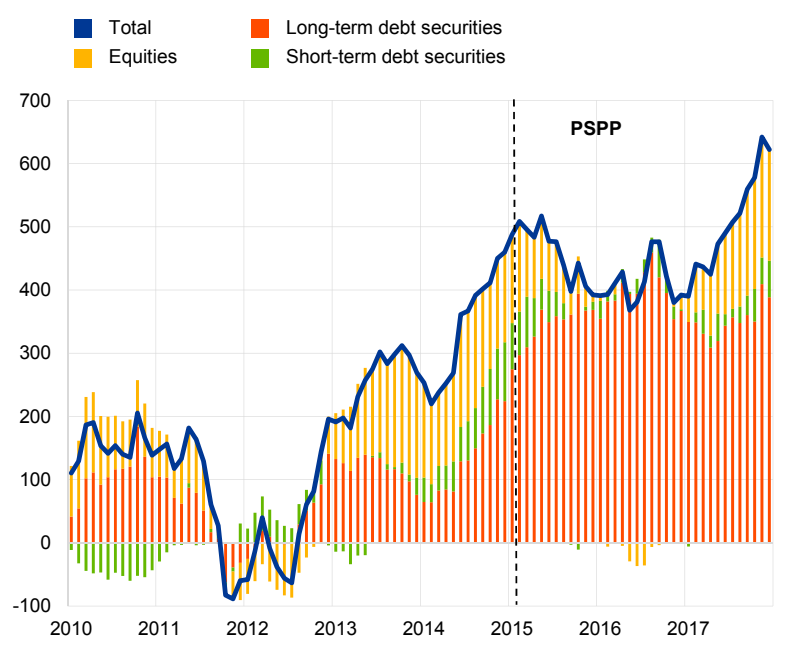

Source: ECB.

Notes: A positive (negative) number indicates net purchases (sales) of non-euro area securities by euro area investors. Equity includes investment fund shares. Last observation is December 2017. 12-month cumulative sums in bn EUR. 
Figure 3: Average Yield to Maturity

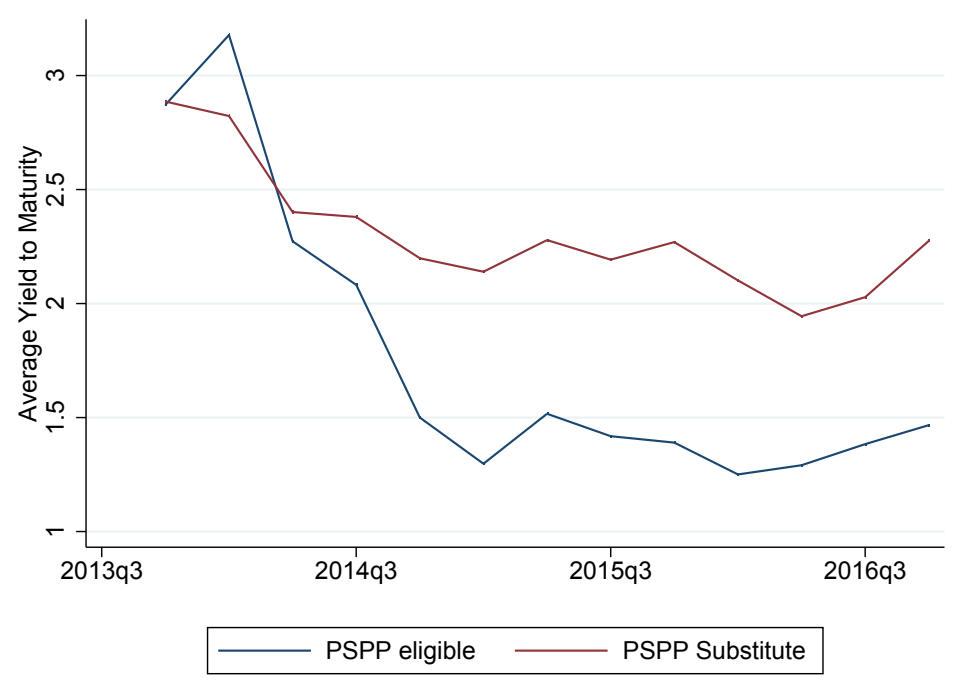

Source: ECB.

Notes: Unweighted average yield to maturity of securities eligible to be bought under PSPP (PSPP eligible) vs. comparable securities outside the euro area (PSPP substitutes). PSPP eligible and PSPP substitute as defined in 2.3.1.

Figure 4: Euro area net debt transactions

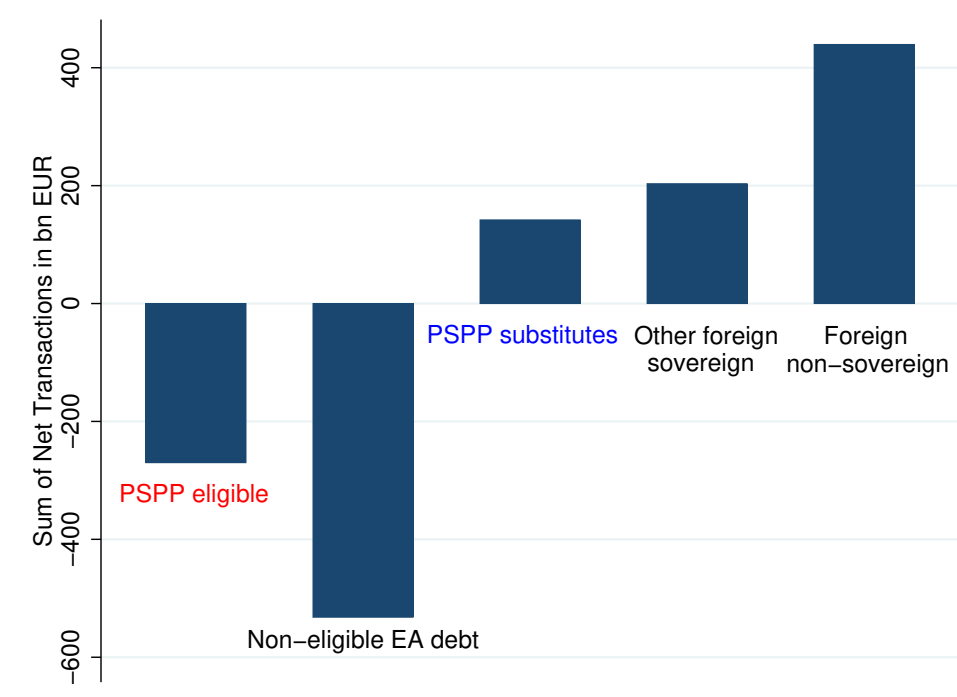

Source: ECB

Notes: Cumulated net purchases by euro area residents from 2015Q1-2016Q4 in EUR bn. PSPP eligible and PSPP substitute as defined in 2.3.1. 
Figure 5: Euro area net debt transactions by sector

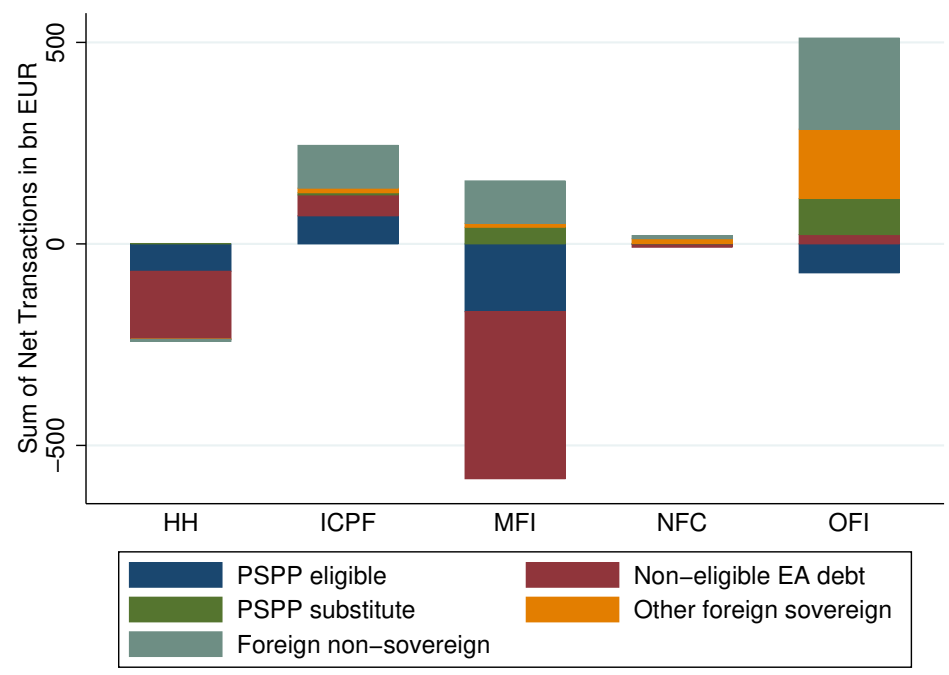

Source: ECB

Notes: Cumulated net purchases by euro area residents from 2015Q1-2016Q4 in EUR bn. PSPP eligible and PSPP substitute as defined in 2.3.1.

Figure 6: Euro area net debt transactions by country

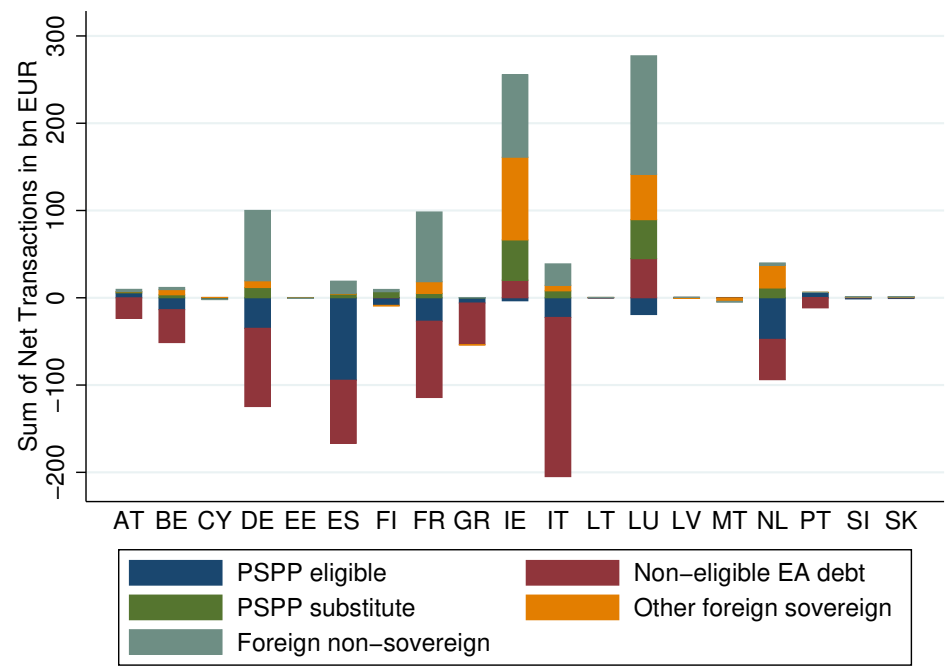

Source: ECB

Notes: Cumulated net purchases by euro area residents from 2015Q1-2016Q4 in EUR bn. PSPP eligible and PSPP substitute as defined in 2.3.1. 
Figure 7: Euro area net transactions: intra-(LHS) and extra-euro area (RHS)
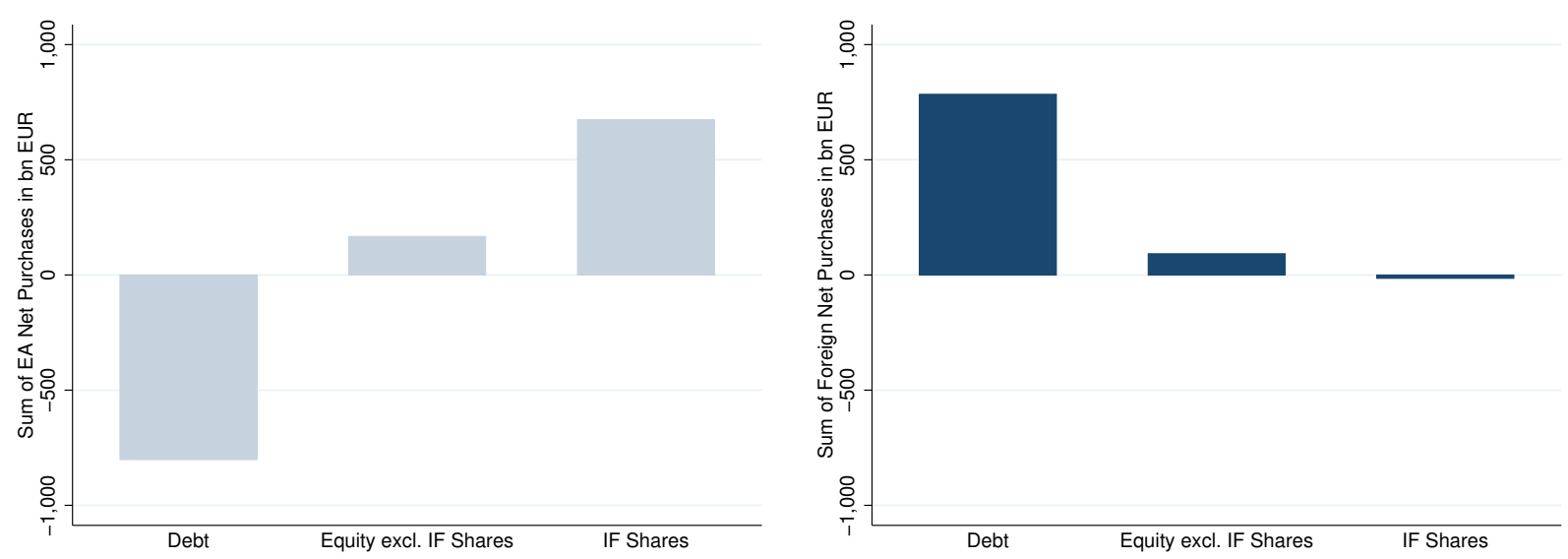

Source: ECB

Notes: Cumulated net purchases by euro area residents from 2015Q1-2016Q4 in EUR bn. Securities on the left (right) issued in (outside) the euro area.

Figure 8: Euro area net transactions by sector: intra-(LHS) and extra-euro area (RHS)
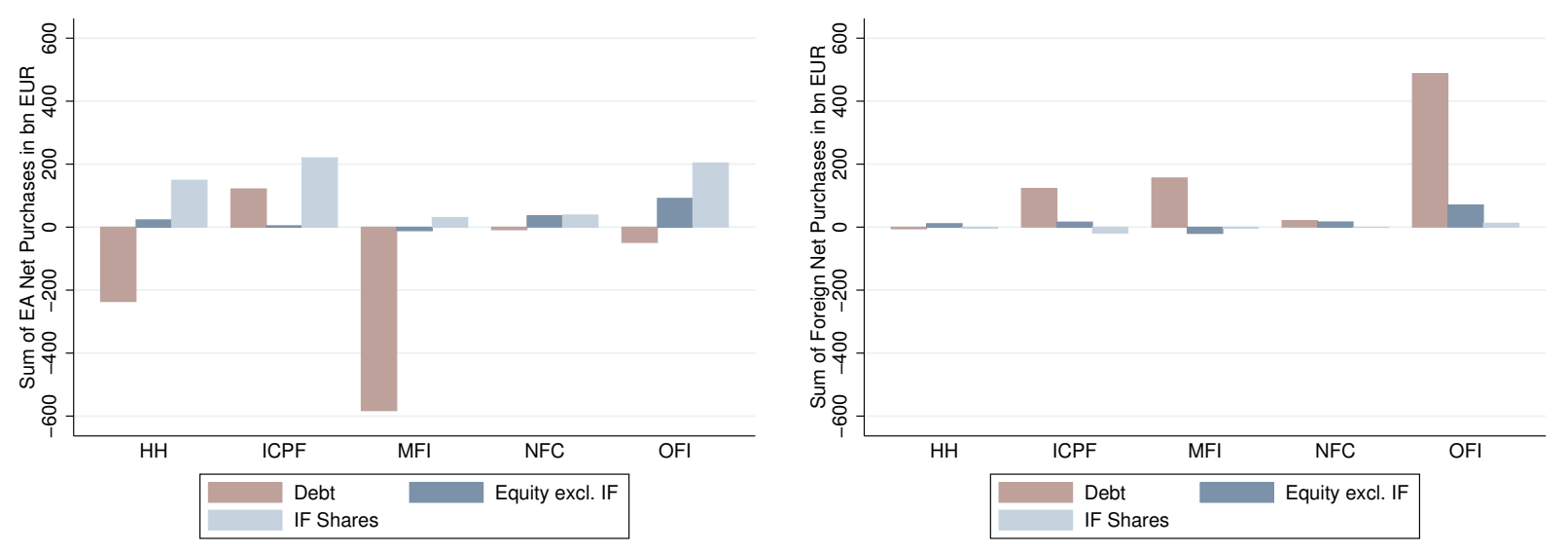

Source: ECB

Notes: Cumulated net purchases by euro area residents from 2015Q1-2016Q4 in EUR bn. Securities on the left (right) issued in (outside) the euro area. 
Figure 9: Euro area net transactions by country: intra-(LHS) and extra-euro area (RHS)
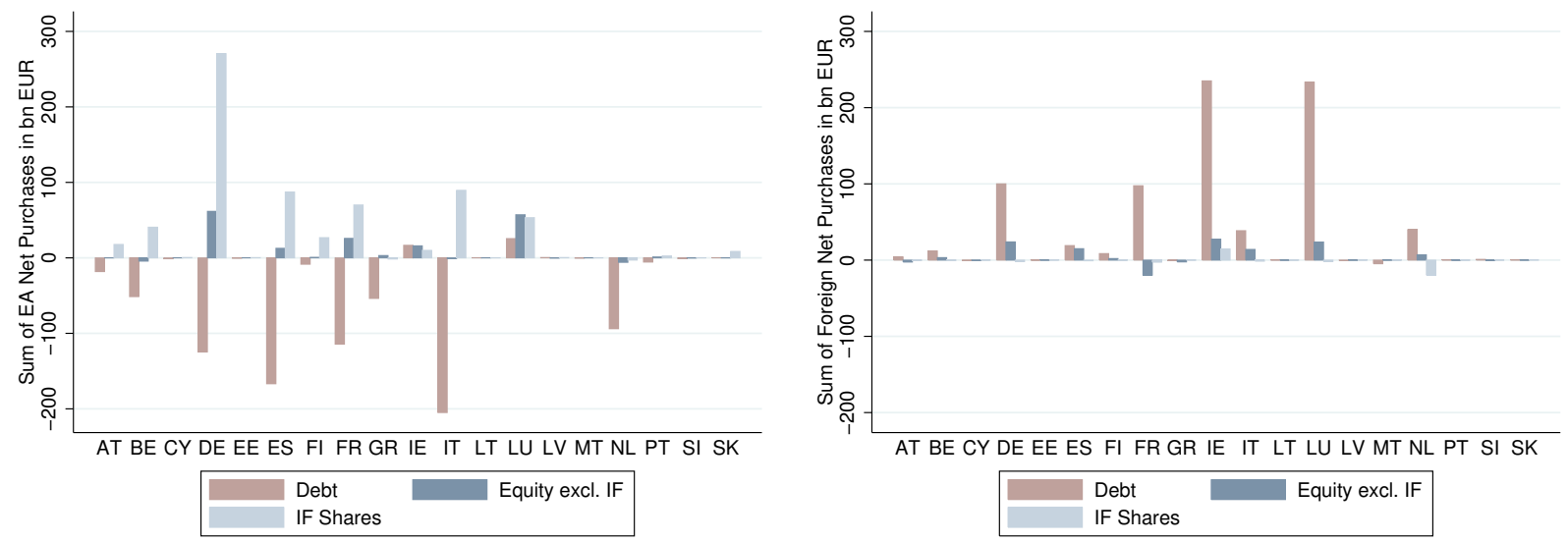

Source: ECB

Notes: Cumulated net purchases by euro area residents from 2015Q1-2016Q4 in EUR bn. Securities on the left (right) issued in (outside) the euro area.

Figure 10: Euro area net transactions of investment fund shares split by their main mandate

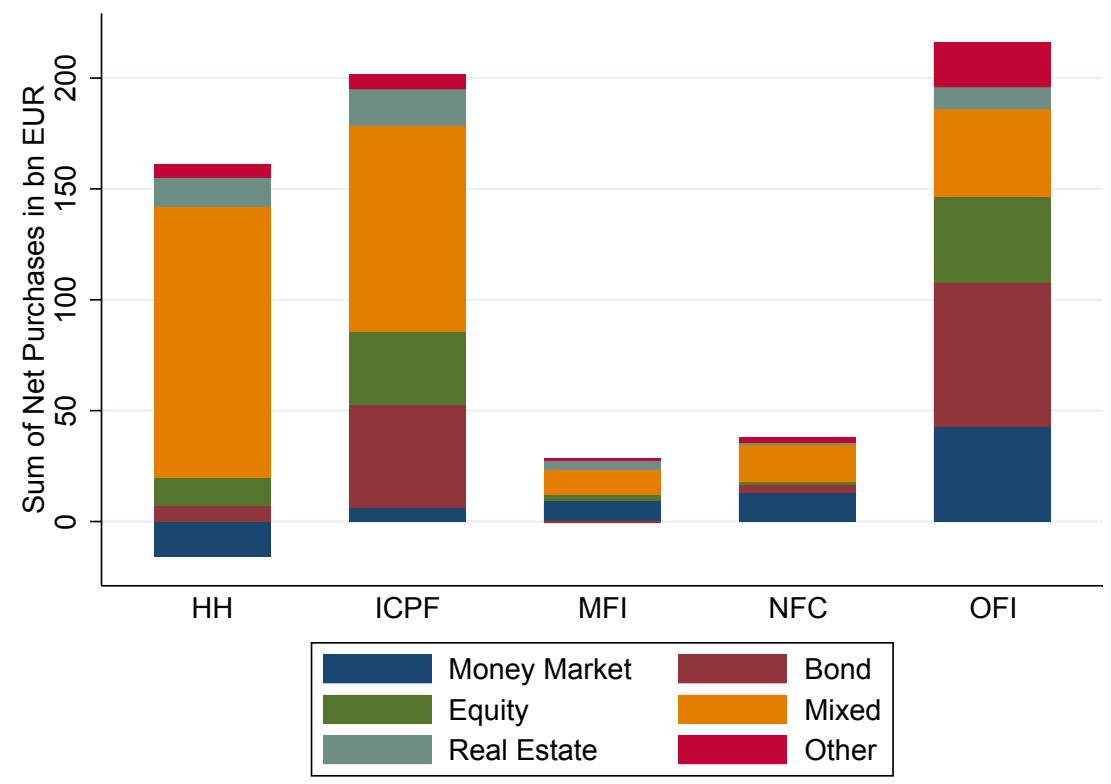

Source: ECB

Notes: Cumulated net purchases of investment fund shares from 2015Q1-2016Q4 split by their respective main mandate of investment in bn EUR. Data on the mandates are from an extract of the CSDB on 31/01/2018. 
Figure 11: Euro area net transactions by geography: debt (LHS) and equity (RHS)
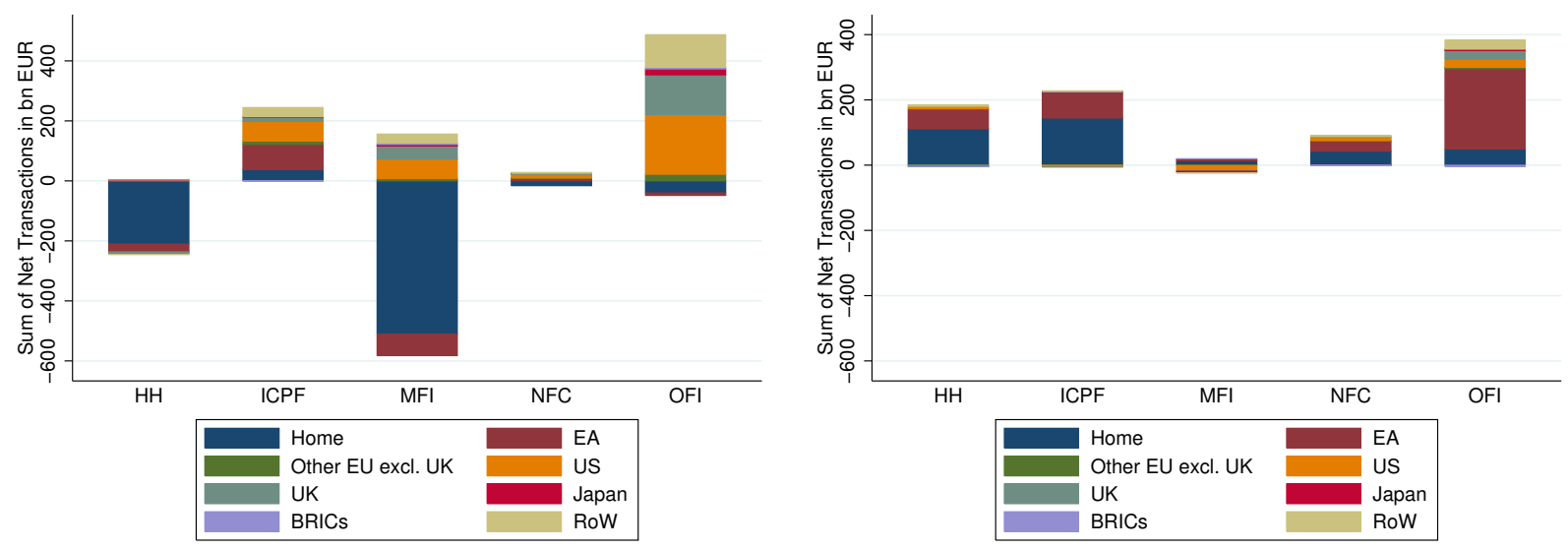

Source: ECB

Notes: Cumulated net purchases by euro area residents from 2015Q1-2016Q4 in EUR bn. Debt securities on the left and equity securities on the right hand side.

Figure 12: Euro area net transactions by currency: debt (LHS) and equity (RHS)
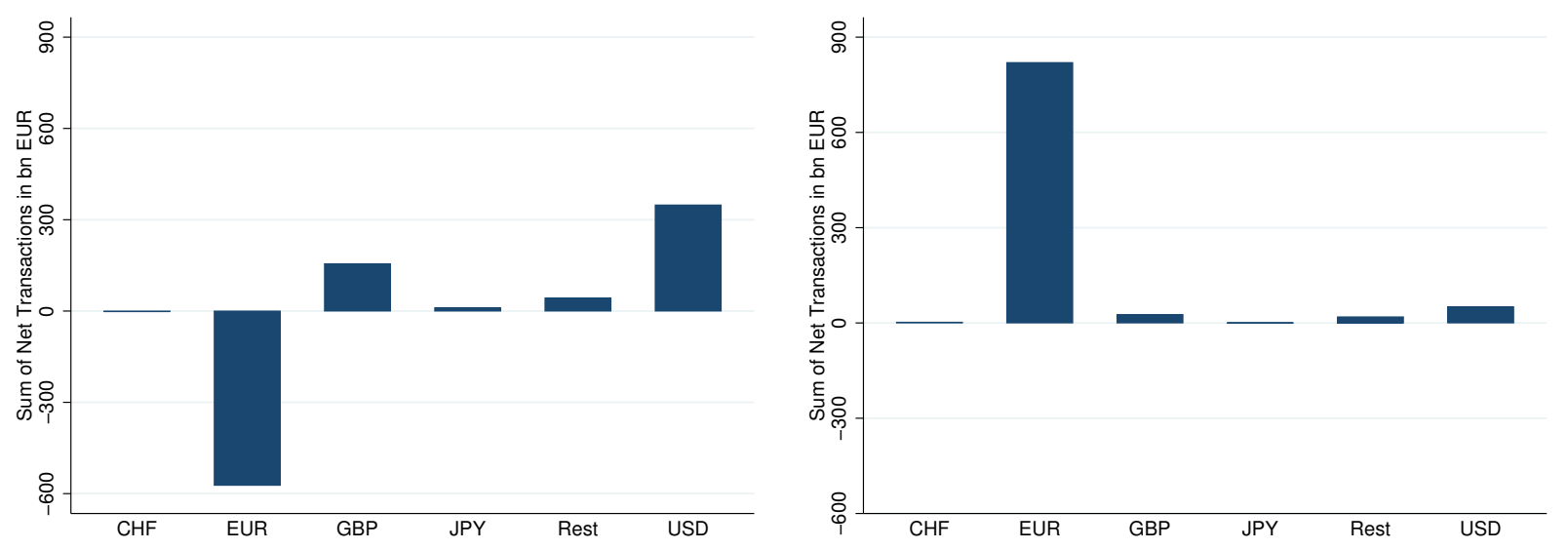

Source: ECB

Notes: Cumulated net purchases by euro area residents from 2015Q1-2016Q4 in EUR bn. Debt securities on the left and equity securities on the right hand side. 
Figure 13: Euro area net transactions by currency: debt (LHS) and equity (RHS)
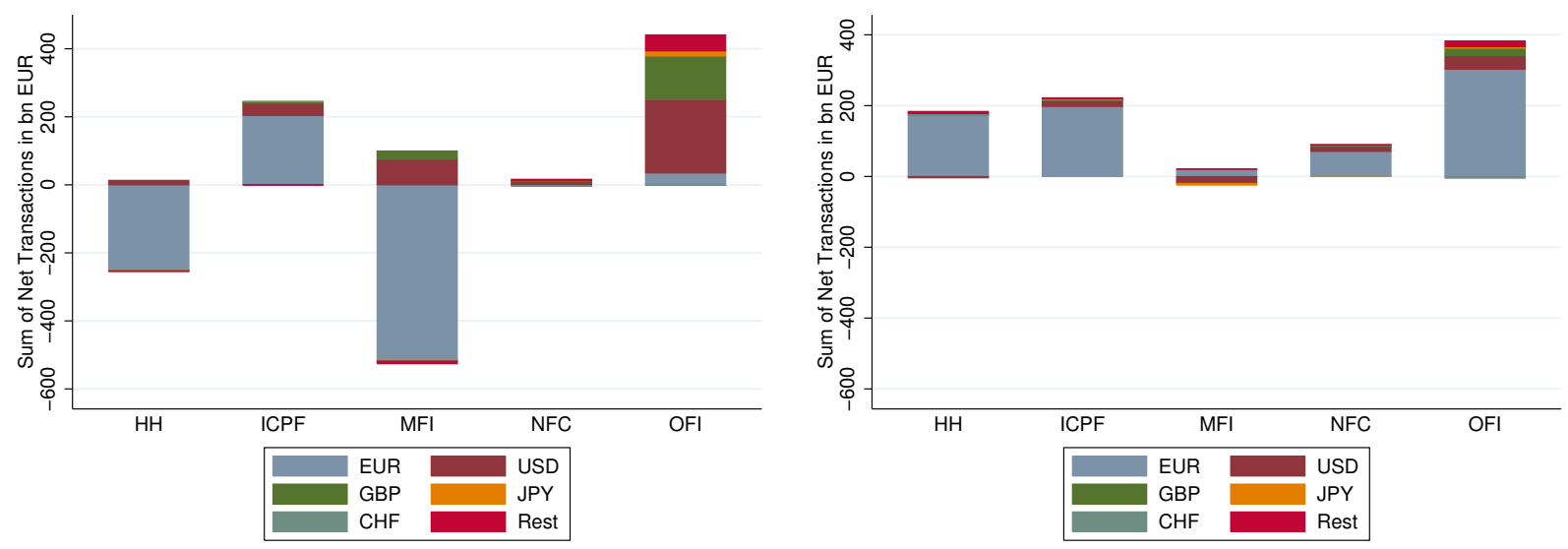

Source: ECB

Notes: Cumulated net purchases by euro area residents from 2015Q1-2016Q4 in EUR bn. Debt securities on the left and equity securities on the right hand side.

Figure 14: Euro area net debt transactions by maturity

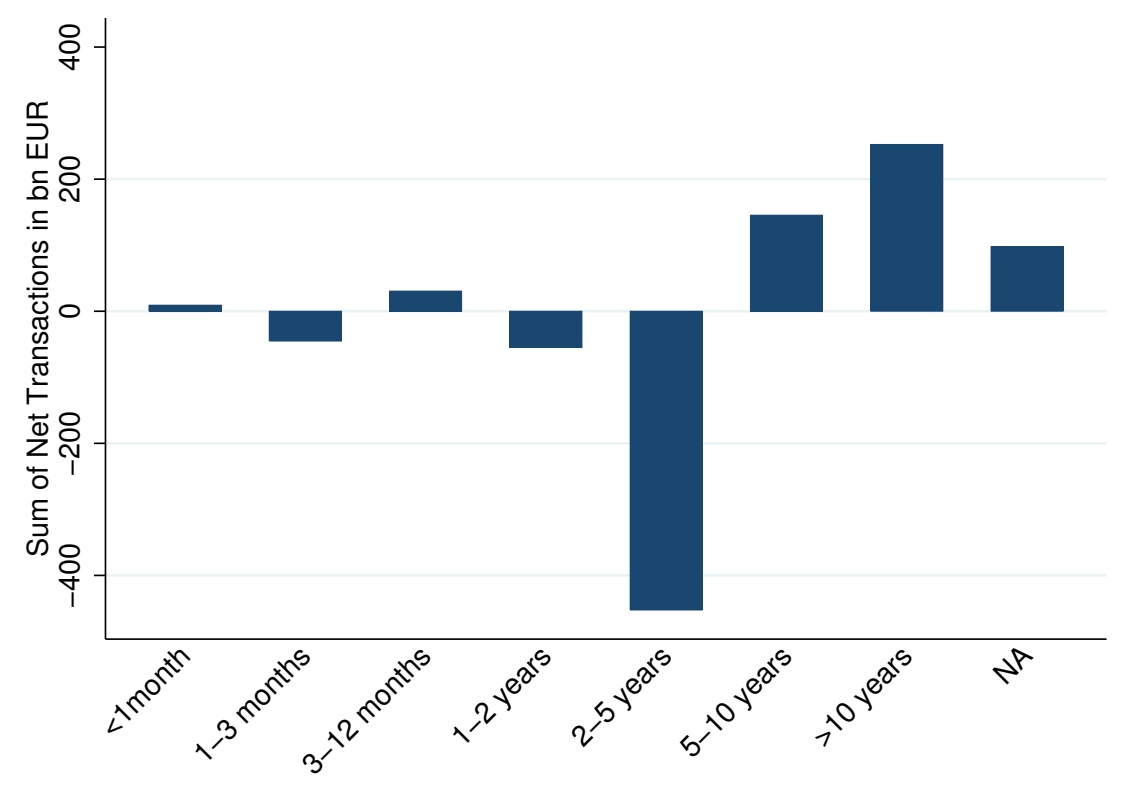

Source: ECB

Notes: Cumulated net purchases by euro area residents from 2015Q1-2016Q4 in EUR bn. 
Figure 15: Euro area net debt transactions by maturity

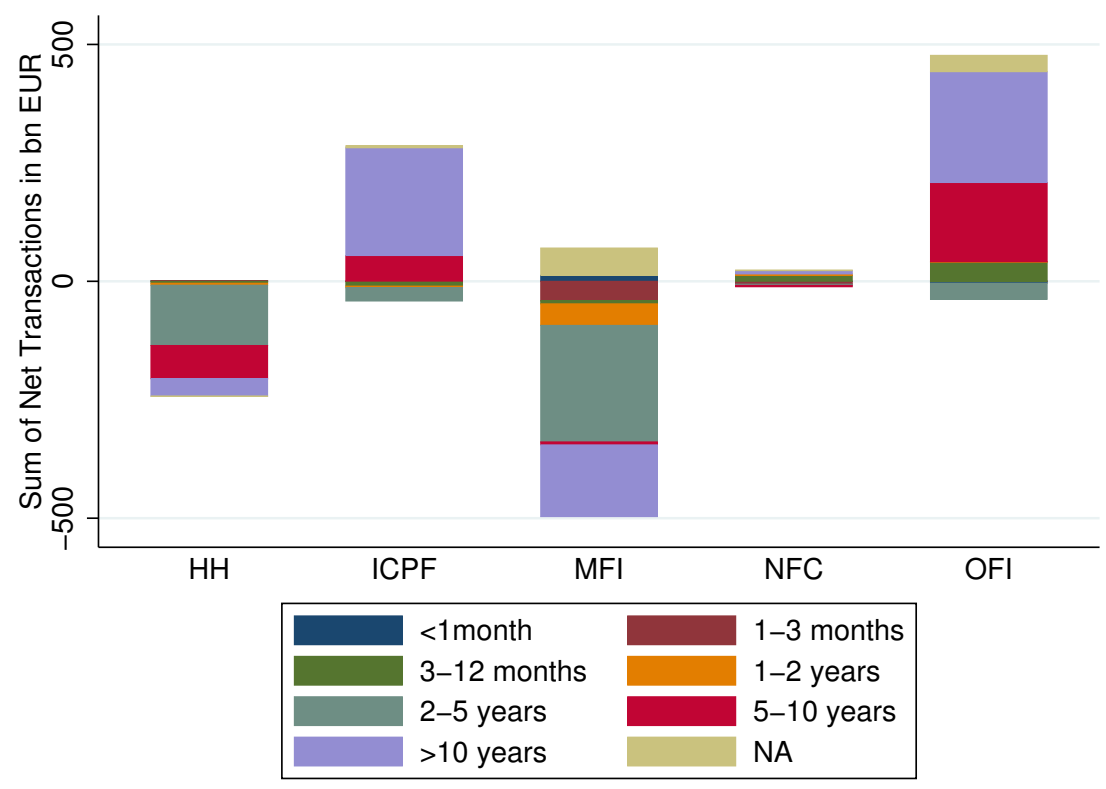

Source: ECB

Notes: Cumulated net purchases by euro area residents from 2015Q1-2016Q4 in EUR bn. 
Figure 16: Euro area net transactions, changes in holdings and valuation effects in PSPP eligible securities, by sector

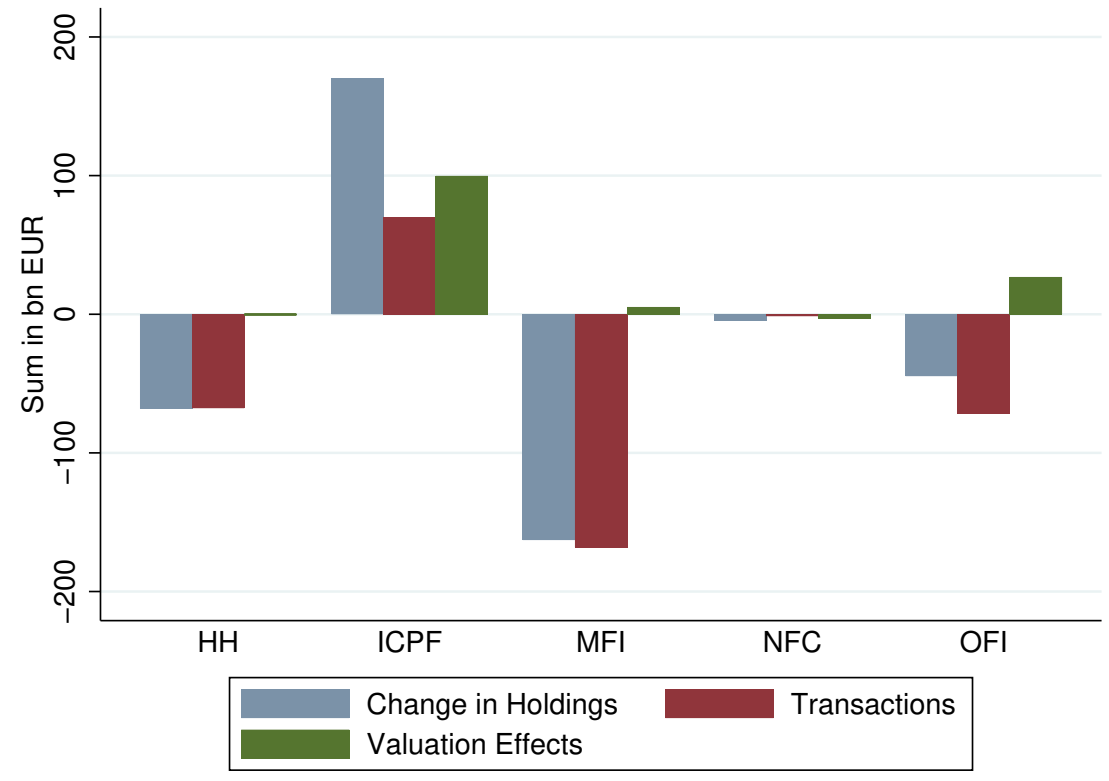

Source: ECB

Notes: Cumulative values from 2015Q1-2016Q4 of PSPP eligible assets by sector in EUR bn. 


\section{Tables}

Table 1: Baseline estimation: debt securities

\begin{tabular}{|c|c|c|c|c|c|c|c|c|}
\hline & $\begin{array}{l}(1) \\
\text { All } \\
\end{array}$ & $\begin{array}{l}(2) \\
\text { All } \\
\end{array}$ & $\begin{array}{c}(3) \\
\text { Foreign }\end{array}$ & $\begin{array}{c}(4) \\
\text { no IE\&LU }\end{array}$ & $\begin{array}{c}(5) \\
\text { only long-term }\end{array}$ & $\begin{array}{l}(6) \\
\text { All } \\
\end{array}$ & $\begin{array}{l}(7) \\
\text { All } \\
\end{array}$ & $\begin{array}{c}\text { (8) } \\
\text { Push-Pull }\end{array}$ \\
\hline $\ln \left(\right.$ Hold $\left._{\text {pre }}\right)$ & $\begin{array}{c}-0.652^{* * * *} \\
(-10.71)\end{array}$ & $\begin{array}{c}-0.652^{* * *} \\
(-10.71)\end{array}$ & $\begin{array}{c}-0.653^{* * *} \\
(-8.42)\end{array}$ & $\begin{array}{c}-0.751^{* * *} \\
(-13.61)\end{array}$ & $\begin{array}{c}-0.657^{* * * *} \\
(-10.44)\end{array}$ & $\begin{array}{c}-0.744^{* * * *} \\
(-9.53)\end{array}$ & $\begin{array}{c}-0.771 \text { *** } \\
(-15.84)\end{array}$ & $\begin{array}{c}-0.553^{* * *} \\
(-7.47)\end{array}$ \\
\hline$\Delta$ Amount Out & $\begin{array}{c}0.505^{* * *} \\
(26.80)\end{array}$ & $\begin{array}{c}0.505^{* * * *} \\
(26.79)\end{array}$ & $\begin{array}{c}0.471^{* * * *} \\
(31.26)\end{array}$ & $\begin{array}{c}0.506^{* * *} \\
(23.35)\end{array}$ & $\begin{array}{c}0.507^{* * *} \\
(26.78)\end{array}$ & $\begin{array}{c}0.540^{* * *} \\
(26.47)\end{array}$ & $\begin{array}{c}0.479 * * * \\
(25.57)\end{array}$ & $\begin{array}{c}0.509^{* * * *} \\
(25.45)\end{array}$ \\
\hline EUR & $\begin{array}{l}-0.327 \\
(-1.22)\end{array}$ & $\begin{array}{l}-0.327 \\
(-1.22)\end{array}$ & $\begin{array}{l}-0.210 \\
(-0.81)\end{array}$ & $\begin{array}{l}-0.284 \\
(-0.85)\end{array}$ & $\begin{array}{l}-0.324 \\
(-1.15)\end{array}$ & $\begin{array}{l}-0.219 \\
(-0.72)\end{array}$ & $\begin{array}{c}0.0139 \\
(0.05)\end{array}$ & $\begin{array}{l}-0.481 \\
(-1.542)\end{array}$ \\
\hline $\ln$ (original maturity) & $\begin{array}{c}0.564^{* * *} \\
(3.60)\end{array}$ & $\begin{array}{c}0.565^{* * * *} \\
(3.59)\end{array}$ & $\begin{array}{c}0.350^{* *} \\
(2.42)\end{array}$ & $\begin{array}{c}0.825^{* * *} \\
(7.03)\end{array}$ & $\begin{array}{c}0.468^{* *} \\
(2.25)\end{array}$ & $\begin{array}{l}0.352 \\
(1.65)\end{array}$ & $\begin{array}{l}0.195 \\
(1.45)\end{array}$ & $\begin{array}{c}0.771^{* * *} \\
(5.072)\end{array}$ \\
\hline PSPP Eligibility & $\begin{array}{c}-0.808^{* * * *} \\
(-3.00)\end{array}$ & $\begin{array}{c}-0.808^{* * *} \\
(-3.00)\end{array}$ & $\begin{array}{c}-0.681^{* *} \\
(-2.39)\end{array}$ & $\begin{array}{c}-0.959 * * * \\
(-3.36)\end{array}$ & $\begin{array}{c}-0.816^{* * * *} \\
(-3.24)\end{array}$ & $\begin{array}{c}-0.925^{* * * *} \\
(-3.27)\end{array}$ & $\begin{array}{c}-0.632^{* *} \\
(-2.46)\end{array}$ & $\begin{array}{l}-0.581^{*} \\
(-1.821)\end{array}$ \\
\hline PSPP Substitute & & $\begin{array}{l}0.293 \\
(0.58)\end{array}$ & $\begin{array}{l}0.141 \\
(0.29)\end{array}$ & $\begin{array}{l}0.482 \\
(1.06)\end{array}$ & $\begin{array}{l}0.493 \\
(0.68)\end{array}$ & $\begin{array}{l}0.119 \\
(0.19)\end{array}$ & $\begin{array}{l}-0.475 \\
(-0.81)\end{array}$ & $\begin{array}{c}0.520 \\
(0.972)\end{array}$ \\
\hline High Yield & & & & & & $\begin{array}{c}0.0125 \\
(0.08)\end{array}$ & & \\
\hline Low Quality & & & & & & & $\begin{array}{l}-0.132 \\
(-0.48)\end{array}$ & \\
\hline Diff. Policy Uncertainty $_{s-h}$ & & & & & & & & $\begin{array}{c}-1.546^{* *} \\
(2.050)\end{array}$ \\
\hline Diff. $\Delta$ GDP Forecast ${ }_{s-h}$ & & & & & & & & $\begin{array}{l}-0.477 \\
(0.331)\end{array}$ \\
\hline Diff. $\Delta$ Yield $_{s-h}$ & & & & & & & & $\begin{array}{c}0.542 \\
(0.905)\end{array}$ \\
\hline Observations & 683007 & 683007 & 460687 & 566399 & 651402 & 306654 & 290771 & 613093 \\
\hline Holder country-sector FE & yes & yes & yes & yes & yes & yes & yes & yes \\
\hline Issuer country-sector FE & yes & yes & yes & yes & yes & yes & yes & yes \\
\hline Country-pair FE & yes & yes & yes & yes & yes & yes & yes & no \\
\hline
\end{tabular}

Notes: The dependent variable is the (adjusted) logarithm of cumulative net purchases of debt securities during the PSPP period (2015q1-2016q4). The independent variables are holdings $\ln \left(\right.$ Hold $\left._{\text {pre }}\right)$ in 2014Q4, the change in the outstanding amounts $\Delta$ Amount Out, a dummy variable for euro denomination EUR and the original maturity ln(original maturity). PSPP eligible and PSPP substitute as defined in 2.3.1. High Yield is a dummy variable equal to 1 if the yield is in the highest decile. Low Quality is a dummy variable equal to 1 if the security is rated on the lowest out of four categories defined by the ECB. Diff. Policy Uncertainty Un $_{h}$ is the average quarterly $(\log )$ difference between news-based policy uncertainty of the issuer country s and holder country h. Diff. $\triangle$ GDP Forecast $t_{s-h}$ is the average difference of revisions in the semiannual forecast (five years ahead) between issuer country s and holder country h. Diff. $\Delta$ Yield $_{s-h}$ is the change in the 10 year government bond yield differential between issuer country s and holder country h. All differences refer to $2014 \mathrm{Q} 4$ to 2016Q4. T-statistics in brackets. ${ }^{*}$ significant at $10 \%$ level; ${ }^{* *}$ significant at $5 \%$ level, ${ }^{* * *}$ significant at $1 \%$ level. 
Table 2: Sectoral estimation: debt securities

\begin{tabular}{|c|c|c|c|c|c|}
\hline & $\begin{array}{c}(1) \\
\text { MFI }\end{array}$ & $\begin{array}{c}(2) \\
\mathrm{ICPF}\end{array}$ & $\begin{array}{c}(3) \\
\text { OFI }\end{array}$ & $\begin{array}{c}(4) \\
\mathrm{NFC}\end{array}$ & $\begin{array}{l}(5) \\
\mathrm{HH}\end{array}$ \\
\hline $\ln \left(\right.$ Hold $\left._{\text {pre }}\right)$ & $\begin{array}{c}-0.709 * * * \\
(-7.20)\end{array}$ & $\begin{array}{c}-0.556^{* * *} \\
(-5.88)\end{array}$ & $\begin{array}{c}-0.526^{* * *} \\
(-4.88)\end{array}$ & $\begin{array}{c}-0.658^{* * *} \\
(-8.58)\end{array}$ & $\begin{array}{c}-0.830^{* * *} \\
(-8.55)\end{array}$ \\
\hline$\Delta$ Amount Out & $\begin{array}{c}0.640^{* * *} \\
(9.37)\end{array}$ & $\begin{array}{c}0.513^{* * *} \\
(11.09)\end{array}$ & $\begin{array}{c}0.487^{* * *} \\
(19.86)\end{array}$ & $\begin{array}{c}0.476^{* * *} \\
(26.29)\end{array}$ & $\begin{array}{c}0.445^{* * *} \\
(20.88)\end{array}$ \\
\hline EUR & $\begin{array}{c}1.085^{* * *} \\
(2.99)\end{array}$ & $\begin{array}{l}0.970 \\
(1.37)\end{array}$ & $\begin{array}{l}-0.112 \\
(-0.40)\end{array}$ & $\begin{array}{c}-0.454^{*} \\
(-1.87)\end{array}$ & $\begin{array}{c}-2.550^{* * *} \\
(-13.18)\end{array}$ \\
\hline $\ln ($ original maturity) & $\begin{array}{l}-0.166 \\
(-0.56)\end{array}$ & $\begin{array}{c}1.258^{* * *} \\
(3.58)\end{array}$ & $\begin{array}{l}0.290 \\
(1.17)\end{array}$ & $\begin{array}{c}0.877^{* * *} \\
(10.33)\end{array}$ & $\begin{array}{c}1.081^{* * *} \\
(11.37)\end{array}$ \\
\hline PSPP eligibility & $\begin{array}{l}-1.370 \\
(-1.34)\end{array}$ & $\begin{array}{c}-0.0993 \\
(-0.25)\end{array}$ & $\begin{array}{c}-1.189^{* * *} \\
(-3.14)\end{array}$ & $\begin{array}{c}-0.908^{*} \\
(-1.92)\end{array}$ & $\begin{array}{c}-1.549 * * * \\
(-4.07)\end{array}$ \\
\hline PSPP substitute & $\begin{array}{c}-0.0952 \\
(-0.09)\end{array}$ & $\begin{array}{l}-0.741 \\
(-0.90)\end{array}$ & $\begin{array}{c}1.725^{* * *} \\
(2.90)\end{array}$ & $\begin{array}{l}-1.026 \\
(-1.13)\end{array}$ & $\begin{array}{c}-0.0372 \\
(-0.05)\end{array}$ \\
\hline Observations & & & 683007 & & \\
\hline Holder country-sector FE & & & yes & & \\
\hline Issuer country-sector FE & & & yes & & \\
\hline Country-pair FE & & & yes & & \\
\hline
\end{tabular}

Notes: The dependent variable is the (adjusted) logarithm of cumulative net purchases of debt securities during the PSPP period (2015q1-2016q4). The independent variables are holdings $l n\left(\right.$ Hold $\left.d_{\text {pre }}\right)$ in 2014Q4, the change in the outstanding amounts $\Delta$ Amount Out, a dummy variable for euro denomination EUR, and the original maturity $\ln$ (original maturity). PSPP eligible and PSPP substitute as defined in 2.3.1. T-statistics in brackets. * significant at $10 \%$ level; ${ }^{* *}$ significant at $5 \%$ level, $* * *$ significant at $1 \%$ level. 
Table 3: Geography estimations

\begin{tabular}{|c|c|c|c|c|c|c|}
\hline & $\begin{array}{c}(1) \\
\text { ALL }\end{array}$ & $\begin{array}{c}(2) \\
\text { MFI }\end{array}$ & $\begin{array}{c}(3) \\
\mathrm{ICPF}\end{array}$ & $\begin{array}{c}(4) \\
\text { OFI }\end{array}$ & $\begin{array}{c}(5) \\
\mathrm{NFC}\end{array}$ & $\begin{array}{l}6) \\
\mathrm{HH}\end{array}$ \\
\hline PSPP Eligibility & $\begin{array}{c}-0.827 * * * \\
(0.267)\end{array}$ & $\begin{array}{l}-0.573 \\
(1.004)\end{array}$ & $\begin{array}{c}0.045 \\
(0.440)\end{array}$ & $\begin{array}{c}-1.359 * * * \\
(0.442)\end{array}$ & $\begin{array}{l}-0.758 \\
(0.458)\end{array}$ & $\begin{array}{c}-1.776 * * * \\
(0.365)\end{array}$ \\
\hline Issuer $=$ EA MFI & $\begin{array}{l}0.256 \\
(0.259)\end{array}$ & $\begin{array}{c}1.988^{* * *} \\
(0.351)\end{array}$ & $\begin{array}{c}0.464 \\
(0.336)\end{array}$ & $\begin{array}{c}0.111 \\
(0.284)\end{array}$ & $\begin{array}{c}0.689 * * * \\
(0.259)\end{array}$ & $\begin{array}{l}-0.152 \\
(0.199)\end{array}$ \\
\hline Issuer $=\mathrm{EA} \mathrm{NFC}$ & $\begin{array}{l}-0.068 \\
(0.356)\end{array}$ & $\begin{array}{c}1.019 \\
(0.912)\end{array}$ & $\begin{array}{c}0.492 \\
(0.432)\end{array}$ & $\begin{array}{c}0.192 \\
(0.497)\end{array}$ & $\begin{array}{l}0.700^{*} \\
(0.420)\end{array}$ & $\begin{array}{c}0.510 \\
(0.471)\end{array}$ \\
\hline Issuer $=\mathrm{EA} \mathrm{OFI}$ & $\begin{array}{c}0.587^{* *} \\
(0.256)\end{array}$ & $\begin{array}{c}0.517 \\
(0.382)\end{array}$ & $\begin{array}{l}-0.044 \\
(0.302)\end{array}$ & $\begin{array}{c}0.319 \\
(0.247)\end{array}$ & $\begin{array}{c}0.509^{* *} \\
(0.234)\end{array}$ & $\begin{array}{c}0.583^{* *} \\
(0.259)\end{array}$ \\
\hline Issuer $=\mathrm{EA}$ ICPF & $\begin{array}{l}-0.073 \\
(0.705)\end{array}$ & $\begin{array}{l}1.039 \\
(2.401)\end{array}$ & $\begin{array}{c}0.074 \\
(1.103)\end{array}$ & $\begin{array}{l}-0.424 \\
(1.457)\end{array}$ & $\begin{array}{l}-0.595 \\
(0.926)\end{array}$ & $\begin{array}{c}0.735 \\
(1.310)\end{array}$ \\
\hline PSPP Substitute & $\begin{array}{c}0.435 \\
(0.489)\end{array}$ & $\begin{array}{c}0.628 \\
(1.071)\end{array}$ & $\begin{array}{l}-0.047 \\
(0.795)\end{array}$ & $\begin{array}{c}1.704^{* * *} \\
(0.632)\end{array}$ & $\begin{array}{l}-0.596 \\
(0.898)\end{array}$ & $\begin{array}{c}0.521 \\
(0.737)\end{array}$ \\
\hline Issuer $=\mathrm{ADV}$ MFI & $\begin{array}{c}1.554^{* * *} \\
(0.359)\end{array}$ & $\begin{array}{c}2.422^{* * *} \\
(0.396)\end{array}$ & $\begin{array}{c}2.111^{* * *} \\
(0.467)\end{array}$ & $\begin{array}{l}1.254^{* *} \\
(0.515)\end{array}$ & $\begin{array}{c}1.240^{* * *} \\
(0.409)\end{array}$ & $\begin{array}{c}1.157^{* * *} \\
(0.337)\end{array}$ \\
\hline Issuer $=\mathrm{ADV} \mathrm{NFC}$ & $\begin{array}{c}0.969 \\
(0.603)\end{array}$ & $\begin{array}{c}0.933 \\
(0.802)\end{array}$ & $\begin{array}{c}1.675^{* * *} \\
(0.594)\end{array}$ & $\begin{array}{c}1.026 \\
(0.692)\end{array}$ & $\begin{array}{c}0.693 \\
(0.700)\end{array}$ & $\begin{array}{c}1.627^{* * *} \\
(0.566)\end{array}$ \\
\hline Issuer $=\mathrm{ADV}$ OFI & $\begin{array}{c}3.846^{* * *} \\
(0.336)\end{array}$ & $\begin{array}{c}4.123^{* * *} \\
(0.540)\end{array}$ & $\begin{array}{c}4.864^{* * *} \\
(0.459)\end{array}$ & $\begin{array}{c}2.687 * * * \\
(0.355)\end{array}$ & $\begin{array}{c}4.090^{* * *} \\
(0.542)\end{array}$ & $\begin{array}{c}4.995^{* * *} \\
(0.469)\end{array}$ \\
\hline Issuer $=\mathrm{ADV}$ ICPF & $\begin{array}{l}1.280 \\
(0.784)\end{array}$ & $\begin{array}{l}-2.262 \\
(1.660)\end{array}$ & $\begin{array}{l}-0.590 \\
(1.251)\end{array}$ & $\begin{array}{l}1.954^{* *} \\
(0.859)\end{array}$ & $\begin{array}{l}-2.087 \\
(1.873)\end{array}$ & $\begin{array}{c}0.357 \\
(0.915)\end{array}$ \\
\hline Issuer = EM Corp & $\begin{array}{l}-1.243 \\
(0.808)\end{array}$ & $\begin{array}{l}-1.131 \\
(0.928)\end{array}$ & $\begin{array}{l}-1.116 \\
(0.810)\end{array}$ & $\begin{array}{l}-1.425 \\
(0.919)\end{array}$ & $\begin{array}{l}-0.783 \\
(1.005)\end{array}$ & $\begin{array}{c}0.411 \\
(0.829)\end{array}$ \\
\hline Issuer = EM Sov & $\begin{array}{l}0.954^{*} \\
(0.569)\end{array}$ & $\begin{array}{c}2.126^{* * *} \\
(0.568)\end{array}$ & $\begin{array}{c}1.425 \\
(0.952)\end{array}$ & $\begin{array}{c}0.757 \\
(0.717)\end{array}$ & $\begin{array}{c}-1.602^{* *} \\
(0.734)\end{array}$ & $\begin{array}{l}-0.294 \\
(0.615)\end{array}$ \\
\hline Observations & 683,007 & & & 683,007 & & \\
\hline $\begin{array}{l}\text { Holder country-sector FE } \\
\text { Issuer country-sector FE } \\
\text { Country-pair FE }\end{array}$ & $\begin{array}{l}\text { yes } \\
\text { yes } \\
\text { yes }\end{array}$ & & & $\begin{array}{l}\text { yes } \\
\text { yes } \\
\text { yes }\end{array}$ & & \\
\hline
\end{tabular}

Notes: The dependent variable is the (adjusted) logarithm of cumulative net purchases of debt securities during the PSPP period (2015q1-2016q4). The independent variables are holdings $\ln \left(\right.$ Hold $d_{\text {pre }}$ ) in $2014 \mathrm{Q} 4$, the change in the outstanding amounts $\Delta$ Amount Out, a dummy variable for euro denomination EUR, and the original maturity ln(original maturity). PSPP eligible and PSPP substitute as defined in 2.3.1. ADV stands for advanced countries which include Australia, Canada, Czech Republic, Denmark, Hong Kong, Japan, New Zealand, Norway, Singapore, Sweden, Switzerland, United Kingdom, and the United States. EM stands for emerging market economies. T-statistics in brackets. * significant at $10 \%$ level; $* *$ significant at $5 \%$ level, *** significant at $1 \%$ level. 
Table 4: Country-group estimation

\begin{tabular}{|c|c|c|}
\hline & $\begin{array}{c}1) \\
\text { Debt } \\
\text { Stressed }\end{array}$ & $\begin{array}{c}(2) \\
\text { Debt } \\
\text { Non-stressed }\end{array}$ \\
\hline $\ln \left(\right.$ Hold $\left._{\text {pre }}\right)$ & $\begin{array}{c}-0.904^{* * *} \\
(-9.89)\end{array}$ & $\begin{array}{c}-0.712^{* * *} \\
(-13.45)\end{array}$ \\
\hline$\Delta$ Amount Out & $\begin{array}{c}0.547^{* * *} \\
(9.55)\end{array}$ & $\begin{array}{c}0.495^{* * *} \\
(24.03)\end{array}$ \\
\hline EUR & $\begin{array}{l}0.178 \\
(0.28)\end{array}$ & $\begin{array}{l}-0.407 \\
(-1.08)\end{array}$ \\
\hline $\ln$ (original maturity) & $\begin{array}{l}0.385 \\
(1.46)\end{array}$ & $\begin{array}{c}0.908^{* * *} \\
(8.63)\end{array}$ \\
\hline PSPP eligibility & $\begin{array}{c}-1.750^{* *} \\
(-2.31)\end{array}$ & $\begin{array}{c}-0.685^{*} \\
(-1.86)\end{array}$ \\
\hline PSPP substitute & $\begin{array}{l}0.728 \\
(1.08)\end{array}$ & $\begin{array}{l}0.300 \\
(0.65)\end{array}$ \\
\hline Observations & \multicolumn{2}{|c|}{566399} \\
\hline Holder country-sector FE & \multicolumn{2}{|r|}{ yes } \\
\hline Issuer country-sector FE & \multicolumn{2}{|r|}{ yes } \\
\hline Country-pair FE & \multicolumn{2}{|r|}{ yes } \\
\hline
\end{tabular}

Notes: The dependent variable is the (adjusted) logarithm of cumulative net purchases of debt securities during the PSPP period (2015q1-2016q4). The independent variables are holdings $\ln \left(\right.$ Hold $\left.d_{\text {pre }}\right)$ in $2014 \mathrm{Q} 4$, the change in the outstanding amounts $\Delta$ Amount Out, a dummy variable for euro denomination EUR, and the original maturity ln (original maturity). PSPP eligible and PSPP substitute as defined in 2.3.1. The group of formerly stressed countries consists of Cyprus, Greece, Italy, Portugal and Spain. Ireland and Luxembourg are not included in these estimations. T-statistics in brackets. ${ }^{*}$ significant at $10 \%$ level; ${ }^{* *}$ significant at $5 \%$ level, ${ }^{* * *}$ significant at $1 \%$ level. 
Table 5: Extension of the baseline estimation: Time Dimension

\begin{tabular}{lcccc}
\hline & $(1)$ & $(2)$ & $(3)$ & $(4)$ \\
& From 14Q3 & From 15Q1 & From 15Q1 & From 15Q1 \\
& until 14Q4 & until 15Q2 & until 16Q2 & until 16Q4 \\
\hline & & & & \\
$\ln \left(\right.$ Hold $\left._{\text {pre }}\right)$ & $-0.431^{* * *}$ & $-0.298^{* * *}$ & $-0.589^{* * *}$ & $-0.652^{* * *}$ \\
& $(-4.79)$ & $(-3.50)$ & $(-9.50)$ & $(-10.71)$ \\
$\Delta$ Amount Out & $0.578^{* * *}$ & $0.661^{* * *}$ & $0.542^{* * *}$ & $0.505^{* * *}$ \\
& $(21.08)$ & $(19.00)$ & $(28.22)$ & $(26.79)$ \\
EUR & -0.543 & $-0.577^{* *}$ & $-0.626^{* *}$ & -0.327 \\
& $(-1.52)$ & $(-2.45)$ & $(-2.40)$ & $(-1.22)$ \\
$\ln ($ original maturity) & $0.307^{*}$ & $0.328^{*}$ & $0.444^{* *}$ & $0.565^{* * *}$ \\
& $(1.70)$ & $(1.68)$ & $(2.55)$ & $(3.59)$ \\
PSPP eligibility & $1.226^{* * *}$ & $-0.425^{*}$ & $-1.047^{* * *}$ & $-0.808^{* * *}$ \\
& $(3.42)$ & $(-1.69)$ & $(-4.64)$ & $(-3.00)$ \\
PSPP substitute & $0.899^{*}$ & 0.0452 & 0.101 & 0.293 \\
& $(1.88)$ & $(0.12)$ & $(0.21)$ & $(0.58)$ \\
& & & & \\
\hline Observations & 347851 & 689561 & 684168 & 683007 \\
\hline Holder country-sector FE & yes & yes & yes & yes \\
Issuer country-sector FE & yes & yes & yes & yes \\
Country-pair FE & yes & yes & yes & yes \\
\hline
\end{tabular}

Notes: The dependent variable is the (adjusted) logarithm of cumulative net purchases of debt securities during the period specified on top of the column. The independent variables are holdings $\ln \left(\right.$ Hold $\left._{\text {pre }}\right)$ in $2014 \mathrm{Q} 4$, the change in the outstanding amounts $\Delta$ Amount Out, a dummy variable for euro denomination EUR, and the original maturity ln(original maturity). T-statistics in brackets. PSPP eligible and PSPP substitute as defined in 2.3.1. * significant at $10 \%$ level; ${ }^{* *}$ significant at $5 \%$ level, ${ }^{* * *}$ significant at $1 \%$ level. 
Table 6: Time Dimension and PSPP eligibility: overall and by sector

\begin{tabular}{lllll}
\hline & $(1)$ & $(2)$ & $(3)$ & $(4)$ \\
& $\begin{array}{l}\text { From 14Q3 } \\
\text { until 14Q4 }\end{array}$ & $\begin{array}{l}\text { From 15Q1 } \\
\text { until 15Q2 }\end{array}$ & $\begin{array}{l}\text { From 15Q1 } \\
\text { until 16Q2 }\end{array}$ & $\begin{array}{l}\text { From 15Q1 } \\
\text { until 16Q4 }\end{array}$ \\
\hline I. Overall specification & & & & \\
& $1.226^{* * *}$ & $-0.425^{*}$ & $-1.047^{* * *}$ & $-0.808^{* * *}$ \\
& $(3.42)$ & $(-1.69)$ & $(-4.64)$ & $(-3.00)$ \\
\hline II. Sectoral specification & & & & \\
MFI & 0.760 & $-1.243^{*}$ & -1.525 & -1.370 \\
& $(0.69)$ & $(-1.67)$ & $(-1.61)$ & $(-1.34)$ \\
ICPF & 1.285 & -0.305 & -0.499 & -0.0993 \\
& $(1.54)$ & $(-0.72)$ & $(-1.11)$ & $(-0.25)$ \\
OFI & $1.435^{* * *}$ & -0.111 & $-1.035^{* * *}$ & $-1.189^{* * *}$ \\
& $(3.78)$ & $(-0.31)$ & $(-3.21)$ & $(-3.14)$ \\
NFC & -0.0304 & -0.896 & $-1.046^{*}$ & $-0.908^{*}$ \\
& $(-0.06)$ & $(-1.44)$ & $(-1.73)$ & $(-1.92)$ \\
HH & 0.768 & $-0.627^{*}$ & $-1.519^{* * *}$ & $-1.549^{* * *}$ \\
& $(1.50)$ & $(-1.73)$ & $(-4.09)$ & $(-4.07)$ \\
& & & & \\
\hline Observations & 347851 & 689561 & 684168 & 683007 \\
\hline Holder country-sector FE & yes & yes & yes & yes \\
Issuer country-sector FE & yes & yes & yes & yes \\
Country-pair FE & yes & yes & yes & yes \\
\hline
\end{tabular}

Notes: Excerpts from full regression tables as in Table 5: coefficients of PSPP Eligibility. The same number of observations is used in both specifications. The dependent variable is the (adjusted) logarithm of cumulative net purchases of debt securities during the period specified on top of the column. T-statistics in brackets. ${ }^{*}$ significant at $10 \%$ level; ${ }^{* *}$ significant at $5 \%$ level, $* * *$ significant at $1 \%$ level. 
Table 7: Extension: Active vs. Passive Rebalancing and PSPP eligibility

\begin{tabular}{lccc}
\hline & $(1)$ & $(2)$ & $(3)$ \\
& Net transactions & Passive rebalancing & $\Delta$ Holdings \\
\hline I. Overall specification & & & \\
& $-1.541^{* * *}$ & $1.492^{* * *}$ & -0.0485 \\
& $(-4.61)$ & $(4.78)$ & $(-1.37)$ \\
\hline II. Sectoral specification & & & \\
MFI & $-2.505^{*}$ & $2.541^{* *}$ & 0.0358 \\
& $(-1.96)$ & $(2.19)$ & $(0.28)$ \\
ICPF & -0.351 & 0.379 & 0.0278 \\
& $(-0.75)$ & $(0.83)$ & $(0.69)$ \\
OFI & $-1.963^{* * *}$ & $1.961^{* * *}$ & -0.00162 \\
& $(-3.34)$ & $(3.51)$ & $(-0.04)$ \\
NFC & -0.920 & 0.906 & -0.0138 \\
& $(-1.29)$ & $(1.33)$ & $(-0.27)$ \\
HH & $-1.950^{* * *}$ & $1.738^{* * *}$ & $-0.212^{* * *}$ \\
& $(-3.30)$ & $(3.23)$ & $(-2.92)$ \\
\hline Observations & 331356 & 331356 & 331356 \\
Holder country-sector FE & yes & yes & yes \\
Issuer country-sector FE & yes & yes & yes \\
Country-pair FE & yes & yes & yes \\
\hline
\end{tabular}

Notes: Excerpts from full regression tables: coefficients of PSPP Eligibility. The same number of observations is used in both sets of estimations. The dependent variable is for column (1) the (adjusted) logarithm of cumulative net purchases of debt securities during the PSPP period (2015q1-2016q4), for column (3) the log change in holdings from end of 2014Q4 until 2016Q4, and for column (2) the difference between (3) and (1). T-statistics in brackets. * significant at $10 \%$ level; ${ }^{* *}$ significant at $5 \%$ level, $* * *$ significant at $1 \%$ level. 